\title{
RETHINKING MUST-CARRY AND RETRANSMISSION CONSENT REGULATION IN THE DIGITAL ERA
}

Submitted: 29/05/2019

Revised: $15 / 07 / 2019$

Accepted: $25 / 07 / 2019$

\author{
Clara-Luz Alvarez *
}

\begin{abstract}
Purpose - The emergence of new technological platforms to access online services and content have transformed the media landscape dramatically. Such transformation requires policymakers to reexamine the decades-old regulations traditionally addressed to broadcasters and telecommunications providers as must-carry and retransmission consent rules. This paper reviews must-carry regulation and case law in the United States of America, Mexico, and France. That is because each one of these countries has offered a variety of justifications for such rules (competition, local content, viewers' rights, diversity). The purpose of this review is to analyze whether or not the original reasons for must-carry regulation are still valid in the digital era.
\end{abstract}

Methodology/approach/design - The research was conducted through document review and analysis of norms and case law from each one of the selected countries (USA, Mexico, and France) based on information collected via academic research. Also, analysis of statistical sources of information was attained to portray the penetration status of telecommunication services over the last decades in order to fully understand the context in which must-carry rules were enacted.

Findings - Policymakers should consider other regulatory mechanisms to achieve the original reasons for must-carry rules. The dramatic increase in the variety of devices (e.g., TV, tablet, mobile phones, smart TVs), service and content distributors (e.g., free-to-air $\mathrm{TV}$, cable TV, internet), and service providers (e.g., broadcasters and over-the-top

*Member of the Mexican National Researchers System (Level III) and researcher of the
Universidad Panamericana (Mexico). She received the National Journalism Award for
spreading democratic culture for her program Código Democracia at the Congress
Channel (2014). Clara-Luz is author of the books Telecomunicaciones yadiodifusión en
México (2018), Telecomunicaciones en la Constitución (2017), El Regulador de
Telecomunicaciones (2017), Derecho de las Telecomunicaciones (3rd ed., 2014) and
Internet y Derechos Fundamentales (2011), and coordinator of the book
Telecomunicaciones y Tecnologías de la Información (2012). She was rapporteur for the
International Telecommunications Union's study group of ICT accessibility for persons
with disabilities (2006-2011), and Commissioner for the Mexican Telecommunications
Commission (Cofetel, 2003-2006). Address: Universidad Panamericana. Facultad de
Derecho. Augusto Rodin 498, México, Ciudad de México, 03920, México. ORCID:
https://orcid.org/0000-0002-5906-4450. B. E-mail: claraluzalvarez@gmail.com,
calvarezg@ @up.edu.mx. Website: www.claraluzalvarez.org. 
internet providers) strongly suggests a reconsideration of the current approach. Yet any amendment to the current regulation will depend on internet penetration and access to new video distribution platforms in a given geographic area. That is to say, without internet access, free-to-air TV might continue to be an important platform for service and content distribution.

Practical implications - Identifying and analyzing the reasons for imposing must-carry rules in connection with the telecommunication services penetration over the past decades, provides the necessary framework to assess the convenience and need to maintain such rules or to introduce changes and identify which modifications must be done to further the objectives pursued in a given country.

Originality/value - This research is original insofar as it analyses must-carry rules and case law of three different countries with their own background and objectives. Mustcarry rules are being enacted in several countries including in those in Latin America. This paper is useful for both policymakers and researchers to provoke an in-depth analysis as to whether must-carry rules should be enacted, amended or eliminated, based on the specific context and objectives pursued in a given country.

Keywords: Must-Carry. Must-Offer. Broadcasting. Pay-Tv. Competition.

\section{INTRODUCTION}

Free-to-air television has been considered an important service that confers social value. This service has provided access to information and entertainment, as well as contributed to freedom of expression, civic participation, and democracy.

Free-to-air television needs spectrum, a public good that is scarce. Therefore, spectrum scarcity ${ }^{1}$ has determined both the available broadcasting stations and the justification for the so-called public trustee obligations or public service obligations imposed on broadcasters. Public trustee obligations bind broadcasters to comply with certain public interest obligations, yet broadcasters are also protected insofar as the social value of their service must be preserved.

Must-carry, in general terms, means the retransmission of free-to-air TV or radio channel programming by telecommunications network operators as in the case of cable TV or satellite TV. ${ }^{2}$ The other side of the must-carry coin is the

\footnotetext{
${ }^{1}$ Spectrum scarcity occurs for several reasons, including the nature of spectrum as a limited natural resource, the existence (or not) of technology to exploit the spectrum, together with regulatory decisions as to whether to grant the use of the spectrum to one or more persons. See Alvarez, C. L., 2016.

${ }^{2}$ Satellite TV is a distribution service of audiovisual content to subscribers, provided by an operator through satellite communication. In the USA, such service is also known as direct broadcast via satellite or DBS.
} 
must-offer rule, which obliges free-to-air TV or radio stations to provide their programming for carriage by telecommunications network operators. Must-carry regulation $^{3}$ has had different backgrounds and rules when enacted in each country.

The main argument of this article is that new platforms to access content may eliminate the justification for upholding the must-carry regulation as it stands today. Therefore, alternative mechanisms should be assessed to promote the original reasons for enacting the must-carry regulation. Any amendment to the current must-carry regulation will depend on internet penetration and new video distribution platforms in a given geographic area, as well as on whether any or all of the reasons behind the must-carry regulation should be preserved in the digital era.

For purposes of this article, the cases of the USA, Mexico, and France were selected. The United States of America was chosen because it clearly presents a long evolution of the regulations for the retransmission of audiovisual content through pay-TV network operators. On its turn, Mexico, as a Latin American country, was picked - for the first time ever-, because it has not only established must-carry and must-offer regulations but also included them in its Constitution in 2013. Lastly, France was selected because, as a Member State of the European Union (EU), it is subject to the European framework, in addition to its own national must-carry regulation set forth both in a law pertaining to freedom of communication and in a code linked to local public services. Despite their very different backgrounds and their own particularities, these three countries have generated case law that reflects scrutiny of the must-carry regulation, its underlying reasons, and objectives, as well as a refusal to acknowledge that online video services are also subject to the must-carry regulation.

In the USA, the must-carry regulation appears as a way to balance the interests of broadcasters and those of telecommunications network operators, with due consideration for viewers' rights. Mexico's must-offer rule for free-toair TV channels was far more important than the must-carry rule since the main free-to-air TV channels held a major share of the television viewers and were almost an essential element for any pay-television operator package. In France, where television was initially only provided by public entities, must-carry regulation emerged as a need to continue with the distribution of public television on cable TV networks as a way to preserve public interest programming.

${ }^{3}$ For purposes of this article, must-carry regulation may also include must offer, retransmission consent rules and the carry one, carry all rule. 
Competition concerns have been one of the reasons for the must-carry regulations in the USA, Mexico, and France. These countries also have other must-carry rationales based on the importance of local news and content (localism), viewers' rights and access to multiple sources of information, as well as diversity and plurality. The bottom line is that there is the assumption that free-to-air TV provides social value and because the spectrum is scarce, the freeto-air TV should, therefore, be preserved somehow.

The broadcast industry was and still is economically powerful, yet the emergence of new platforms for accessing content is changing the media landscape. The time has arrived to assess and to question whether certain regulations - like the must-carry regulation - are still valid in the digital era.

Part I presents the United States of America's experience starting from the emerging retransmission by community cable antenna in view of the poor reception of free-to-air TV in certain communities, passing through the US Supreme Court's decision that made Congress enact a compulsory license through the Copyright Act, and arriving at the current must-carry regulations, retransmission consent and the carry one, carry all rule. The case of IVI, a video streaming service, will then be presented.

Next, Part II expounds the Mexican situation with a high concentration of commercial free-to-air TV service and pay-TV operators, as well as the precedent of the must-offer rule in Mexico. The circumstances around the incorporation of must-carry and must-offer regulations into the Mexican Constitution will be described, together with the singularities of the must-carry regulation and the underlying reasons. Afterward, the must-carry case brought before the Mexican Supreme Court is analyzed and the criteria issued by the Mexican Telecommunications Regulator (Instituto Federal de Telecomunicaciones) in connection with the must-carry rule for online video distribution is explained.

The French experience will be the main subject of Part III. First, the EU's must-carry framework is described. Then the differences between must-carry regulations in the EU vis-à-vis those in the USA and in Mexico are highlighted. France's must-carry regulation is presented, followed by the most important cases on this matter, namely, the PlayTV case regarding an online video distribution service, and the Iliad and Free case regarding the retransmission of local public service programming.

Considering the information of the previous parts, Part IV presents data regarding the penetration of television, telecommunication and internet services over the last decades. This data is important to duly assess the significance that each access platform held for society when the must-carry regulation was enacted, as well as their current status. Finally, there is an evaluation of the 
must-carry regulation in light of the different reasoning and the different scenarios of the digital era, with discoverability presented as a possible alternative to the must-carry rule which should be further researched.

\section{MUST-CARRY AND RETRANSMISSION CONSENT IN THE USA}

The must-carry regulation in the USA has taken multiple paths. Some litigation has involved challenges based on copyright infringements while others were directed at the must-carry regulation. The US Supreme Court has ruled on major cases on the must-carry rules and Congress has tried to enact laws that balance the different interests underlying must-carry regulations.

From the absence of regulation and US Supreme Court's acknowledgment that retransmission by cable TV operators did not infringe copyrights under the then-current regulation, and until regulation enabled broadcasters to decide between the mandatory carriage of their signals without royalty payments or negotiations with cable TV operators, must-carry rules have been a key subject for telecommunications.

In this part, I present a brief reference to the history and evolution of the must-carry regulation in the USA, including the most important case law decided by the Supreme Court which initially triggered amendments to the copyright law. From compulsory license, the must-carry rule and retransmission consent, to the inclusion of satellite TV in the carry one, carry all rule.

Then, the rationale behind must-carry rules and retransmission consent are expounded on the basis of congressional intent and what the judiciary has highlighted in its decisions. Competition appears as one of the essential pillars for the must-carry regulation. Seeking the preservation of localism has also been a fundamental premise for the must-carry regulation, although such regulation in itself does not guarantee media localism for civic engagement, for example. Multiple sources of information and viewers' rights were also expressed as part of the reasons for the must-carry regulation. It is important to keep the reasons in mind in order to see whether this type of regulation is still necessary to further the objectives originally sought, as will be analyzed in Part IV.

Finally, the IVI case is described because cases involving new technologies for distributing online video content have also been brought before in Mexico and France, and are important to assess the future of must-carry rules in the digital era.

\section{History and Evolution}

The retransmission of free-to-air TV signals by cable TV operators was not originally a polemic issue, provided that it was not a threat to the 
broadcasters' market and could even expand the number of its potential viewers (Sylvain 2015; Benjamin et al. 2012). In 1965 90\% of US households had TV, but only $2.3 \%$ had cable TV; by $197597 \%$ of the households already had TVs, yet the percentage of households with cable TV was still limited to $12.6 \%$ (U.S. Census Bureau No. 1440). Nonetheless, cable TV subscribers were growing and cable TV services were becoming a type of potential disruptive competitor.

Lawsuits against cable TV operators gave rise to the US Supreme Court's first precedents (Fortnightly Corp. v. United Artists (1968), and Teleprompter v. CBS (1974)). These confirmed that cable TV operators could capture free-to-air TV signals and retransmit them without infringing copyrights (Benjamin et al., 2012; Sylvain, 2015).

\title{
Compulsory Licenses
}

Although cable TV penetration in households was not yet as significant as to pose an actual and imminent threat to broadcasters (12.6\% in 1975, U.S. Census Bureau, No. 1440), Congress stepped in to override US Supreme Court's decisions by enacting the Copyright Act of 1976 with two major implications: compulsory licenses of free-to-air TV signals for cable TV operators to retransmit without any alteration (a type of must-offer); and royalty payments by cable TV operators for the use of programming (Sylvain, 2015, Benjamin et. Al. 2012). "[...] the legislative process, more than litigation, was far more conducive to resolving the variety of policy concerns -concerns involving competition, the distribution of free programming, and the protection of local broadcasters." (Sylvain, 2015, p. 746).

\begin{abstract}
"Compulsory licensing not only protects the commercial value of copyrighted works but also enhances the ability of cable systems to retransmit such programs [...] thereby allowing the public to benefit by the wider dissemination of works carried on television broadcast signals. [...] The legislative history indicates that Congress enacted $\S 111$ with the intent to address the issue of poor television reception, or, more specifically, to mitigate the difficulties that certain communities and households faced in receiving over-the-air broadcast signals by enabling the expansion of cable systems." (WPIX, Inc. v. ivi, Inc., 2012, pp. 282-283).
\end{abstract}

The enactment of compulsory licensing in 1976 was based on copyright matters rather than other reasons as could be competition, access to multiple sources of information or localism. 


\section{Must-Carry and Retransmission Consent}

More than a decade afterward,

“(...) Congress found that cable operators obtained great benefit from the local broadcast signals that they were able to carry without broadcaster consent or copyright liability, and that this benefit resulted in an effective subsidy to cable operators." (26 FCC Rcd. 2718, 2720, 2011)".

By 1992, $98 \%$ of US households had a TV and $60.2 \%$ had a cable TV subscription (U.S. Census Bureau, No. 1440). Competition between free-to-air TV and cable TV for acquiring and preserving viewers was real and strong.

Consequently, besides the copyright legislation on the matter of mustcarry/must-offer (compulsory license), the Cable Television Consumer and Competition Act of 1992 (the Cable Act) set forth the new regime for either the must-carry rule or retransmission consent of free-to-air TV signals through the so-called multiple video programming distributor (MVPD), which includes cable TV. Every 3 years broadcasters may choose between the compulsory carriage of their signals at no charge (must-carry) (Benjamin et. Al, 2012, p. 498) or negotiating directly with MVPDs, enabling broadcasters to receive a payment, whether in dollars or in-kind ${ }^{4}$ (retransmission consent).

“(..) whose interests does retransmission consent protect? That, unfortunately, is not entirely clear. [...] [Whereas] The logic behind mustcarry is that the protected broadcasters could be significantly harmed were the cable operator to decide not to retransmit their signals and instead to devote the channel capacity to other programming". (Benjamin et. al., 2012, p. 488498).

The reasons underlying both the must-carry rule and retransmission consent will be discussed in the next section.

Large broadcasters with sufficient bargaining power will certainly choose to negotiate retransmission, whereas independent broadcast stations will most likely choose the must-carry rule (Harvard Law Review, 2013, p. 1050). Retransmission consent is subject to negotiations in good faith by broadcasters

${ }^{4}$ Examples of in kind payment are having advertisements in the programming, including in the programming package other channels from the broadcaster, etc. 
and MVPDs (47 CFR 76.65). Nonetheless, there have been impasses due to disputes during negotiations, as well as signal blackouts (Harvard Law Review, 2013, p. 1050). Retransmission consent negotiations may affect broadcasters and cable TV operators, depending on their size and bargaining power. Anyhow, "[s]ubscribers are the innocent bystanders adversely affected when broadcasters and MVPDs fail to reach an agreement to extend or renew their retransmission consent contracts." (26 FCC Rcd. 2718, 2720 (2011)).

Finally, retransmission consent by itself appears no more than an acknowledgment of the possibility of negotiating and achieving an agreement between broadcasters and cable TV under certain rules (e.g., good faith negotiations).

\section{Carry One, Carry All}

Although cable TV penetration in households was not yet as significant as to pose an actual and imminent threat to broadcasters (12.6\% in 1975, U.S. Census Bureau, No. 1440), Congress stepped in to override US Supreme Court's decisions by enacting the Copyright Act of 1976 with two major implications: compulsory licenses of free-to-air TV signals for cable TV operators to retransmit without any alteration (a type of must-offer); and royalty payments by cable TV operators for the use of programming (Sylvain, 2015, Benjamin et. Al. 2012). "[...] the legislative process, more than litigation, was far more conducive to resolving the variety of policy concerns -concerns involving competition, the distribution of free programming, and the protection of local broadcasters." (Sylvain, 2015, p. 746).

Direct broadcast satellite (DBS) providers were included in the obligations for the must-carry rule through the Satellite Home Viewer Improvement Act of 1999, which entered into force in 2001, but with one peculiarity. When a DBS provider decides to carry a local free-to-air TV signal, it must carry all the free-to-air TV channels from that area, which is known as the carry one, carry all provision. US Congress did not want DBS providers to cherry-pick the local stations they would or would not carry.

In case law, the most important government interests considered for the carry one, carry all provisions for DBS services (Satellite Broadcasting and Communications Association v. FCC, 2001) are:

"(1) preserving a multiplicity of local broadcast outlets for over-the-air viewers who do not subscribe to satellite or cable service, and (2) preventing the government's grant of a statutory copyright license to satellite carriers 
from undermining competition in local markets for broadcast television advertising." (Benjamin et. al, 2012, p. 525).

These government interests reflect that the reason behind the carry one, carry all provisions is a competition one: to maintain local broadcasters' existence and financial viability despite DBS competition.

\title{
The Reasoning Behind the Must-Carry Rule and Retransmission Consent
}

Free-to-air services have had so-called public trustee obligations ${ }^{5}$ insofar as they use a natural resource (spectrum) that is deemed scarce. Also, such services have been considered as furthering public interest, and are hence subject to special obligations. The First Amendment challenges regarding regulation on broadcasters face a lower degree of judicial scrutiny compared with newspapers (Benjamin et. al, 2012, Hazlett, 2000).

\begin{abstract}
"In return for this exclusive government license, incumbent broadcasters offered to provide public service. These later became known as the broadcasters 'public interest obligations.' The trade of public airwaves for public interest obligations was the "social contract" between broadcasters and the public. (...) [T]he spectrum belongs to the public, and the public lent it to broadcasters. In that sense, taxpayers (through their governmental representatives) have every right to demand certain behavior - the quo that was supposed to be part of the original quid pro quo." (Beard et al., 2013, p. 20).
\end{abstract}

Notwithstanding that must-carry rules are not exactly a public interest obligation, it is relevant to highlight the special status that broadcasting services have had in the USA and other jurisdictions. "(...) television programming provides a valuable service to the public, including, inter alia, educational, historic, and cultural programming, entertainment, an important source of local news critical for an informed electorate, and exposure to the arts." (WPIX, Inc. v. ivi, Inc., 2012). Additionally, "[t]elevision was the great electronic hearth by which viewers, together, enthusiastically basked in a shared American culture." (Sylvain, 2015).

${ }^{5}$ For more information on the public trustee obligations imposed on broadcasters, see Benjamin et al., 2012, pp. 181-296. 
Also, in a major judicial challenge to must-carry and retransmission consent rules (Turner II), the US Supreme Court, upholding must-carry and retransmission consent regulations, stated that

"[b]roadcast television is an important source of information to many Americans. Though it is but one of many means for communication, by tradition and use for decades now it has been an essential part of the national discourse on subjects across the whole broad spectrum of speech, thought, and expression." (Turner Broad. Sys., Inc. v. FCC, 1997, p. 194).

The important governmental interests ${ }^{6}$ advanced by the must-carry regulation pursuant to the US Supreme Court in Turner II are the following:

“(..) must-carry was designed to serve "three interrelated interests: (1) preserving the benefits of free, over-the-air local broadcast television, (2) promoting the widespread dissemination of information from a multiplicity of sources, and (3) promoting fair competition in the market for television programming (...) [and (4)] 'protecting noncable households from loss of regular television broadcasting service due to competition from cable systems."” (Turner Broad. Sys., Inc. v. FCC, 1997).

It is important to note that pursuant to the US Census Bureau at the time the US Supreme Court decided Turner II, 98\% of households had a TV, $66.5 \%$ received cable TV, but only $18 \%$ had internet subscriptions. These figures must be taken into account while analyzing the Turner II Supreme Court's opinion because few households had internet compared with cable TV service or free-toair TV. In Part IV this issue will be retaken.

\section{Competition}

Broadcast services are characterized as a two-sided market where the percentage of the audience (viewers or listeners) determines the price of the advertisement. The audience does not pay to receive free-to-air TV signals, yet

\footnotetext{
${ }^{6}$ Challenges under First Amendment against regulation are sustained if (1) regulation is content neutral, (2) it advances important governmental interests unrelated to suppression of free speech, and (3) it does not burden speech more than necessary. See Turner Broad. Sys., Inc. v. FCC, 520 U.S. 180, 189 (1997).
} 
an audience is essential for the broadcaster since advertisers are willing to pay as long as there is an audience to receive their messages. If the audience shifts to pay-TV, there is the risk of compromising the financial viability of free-to-air TV stations (Cable Act, §2(a)(16)). The closure of such stations would presumably reduce viewing choices for households without pay-TV services (Hazlett, 2000). "Broadcast television stations both complement and substitute for local cable TV service" (Hazlett, 2000); complement and substitute have to be seen from potential advertisers and also from the viewers' perspective.

In the end, under a competition rationale, the must-carry regulation strengthens the broadcasters' market position (Sylvain, 2015). If broadcasters have sufficient bargaining power, they would choose to negotiate retransmission consent and receive payment; whereas if they do not have such power, they would have the right to have their signal carried through cable TV services.

As the US Supreme Court pointed out, there are interrelated governmental interests at stake in must-carry and retransmission consent regulation. Competition is one such interest. Competition is generally considered a way to create more options for people to freely choose. By having a competitive market, it is assumed that competitors will seek to be different in terms of quality, price, etc.

When enacting cable TV regulation by the Cable Act of 1992, the US Congress stated that the policy was, inter alia, to "(1) promote the availability to the public of a diversity of views and information through cable television and other video distribution media; (2) rely on the marketplace, to the maximum extent feasible, to achieve that availability; [...]." (Cable Act, Preamble $\S$ 2(b)(1) and 2(b)(2).). Do must-carry rules and retransmission consent promote the availability of a diversity of views and information?

Competition as a rationale for the must-carry regulation may be - but not necessarily will be- an instrument to make diverse views and information available, to preserve localism, to have multiple sources of information, etcetera. Nonetheless, competition by itself does not create social goods such as media diversity or plurality, nor does it produce quality programming or local interest programming. Competition means several persons offering a service (e.g. several broadcasters in a specific area); plurality mandates that different points of view (e.g. political, social, cultural) are presented (Alvarez, 2018). These arguments will be dealt with in Part IV below when analyzing whether mustcarry rules are still valid in a digital era.

In the case of DBS, the carry one, carry all rule meant to protect local advertisements market of free-to-air TV stations and to contribute in preserving local TV stations. In other words, there is also a competition rationale behind this rule besides the viewers' right to having local free-to-air TV stations. 


\section{Localism}

Back in 1992, US Congress found that "[b]roadcast television stations continue to be an important source of local news and public affairs programming and other local broadcast services critical to an informed electorate." (Cable Act, Preamble $\S 2(a)(11)$ ). The Cable Act of 1992 set forth several objectives, inter alia, (1) promoting diversity of views through multiple technology media, (2) ensuring the availability of access to local noncommercial educational stations and public television services through cable systems, and (3) continuing the local origination of programming through free-to-air TV (Cable Act, Preamble $\S$ 2(a)(6), 2(a)(7), 2(a)(8) and 2(a)(10)). In the case of DBS, localism is embedded in the objective of preserving local free-to-air TV stations.

The importance of media localism for citizens is debatable. Ali argues that media localism "is important as an element of community building and solidarity, as a catalyst for democracy and civic participation and as part of the cultural industries." (Ali, 2017, pp. 53-54). Benjamin et al. affirm that "access to local TV content is critical to the success of any multichannel video programming distributor (MVPD).” (Benjamin et al., 2012, p. 479). Although this assertion is more linked to competition than it is to the importance of local content for citizenship, Benjamin et al. include local TV content as an essential resource.

On the other side and despite the fact that local TV seems to be the most popular source of news, local news "often touch[es] on crime, accidents, and disasters, and business news" and local TV is not identified as a primary source for civic information (Harvard Law Review, 2013, p. 1049). Furthermore, Hazlett claims that there is more public interest programming done by cable TV than by broadcast stations and that these broadcast TV stations with such types of programs are the ones that negotiate the retransmission consent rather than adopting the compulsory must-carry rule (Hazlett, 2000).

A generic proposition that media localism contributes to citizenship and democracy can ignore the fact that it will depend on what type of media localism there is. Local news and local content can be important for civic engagement, a sense of belonging and bonding within the community, but that depends on the type of local news and content to bear out whether they effectively contribute to representing the local community and its diversity or not.

Moreover, in 1992, when the must-carry and retransmission consent were established, no internet was available for households, nor was there mobile data transmission for the public. By 1999, when the carry one, carry all rules were enacted, households with internet were not the majority (U.S. Census Bureau, 
Appendix Table A. Households with a Computer and Internet Use: 1984 to 2009, Computer and Internet Use in the United States: 1984 to 2009, 2019) ${ }^{7}$. In other words, especially in 1992, to acquire local news through electronic means there were only radio, free-to-air TV and cable TV. This has changed significantly. Currently, a person with internet access through any of the technological platforms would be able to access local news. Moreover, websites and search engines detect the geographical location of an internet user and based on that, they provide information, news, etcetera, that tend to be in the area where the user is accessing or its surroundings. These aspects will be dealt with in Part IV.

\section{Viewers Rights and Multiple Sources of Information}

As the US Congress found that cable TV was highly concentrated, then there could be "barriers to entry for new programmers and a reduction in the number of media voices available to consumers." (Cable Act, § 2(a)(4)). The US Court went further to acknowledge that there is also a congressional interest "in preserving a multiplicity of broadcasters to ensure that all households have access to information and entertainment on an equal footing with those who subscribe to cable" (Turner Broad. Sys., Inc. v. FCC, 1997, p. 194). For Carry One, Carry All rules applicable to DBS, there is also recognition that such rules are meant to also preserve local free-to-air TV programming for viewers with pay-TV.

These objectives are linked to viewers' rights or audience rights rather than to competition objectives. TV viewers are both citizens and consumers, yet competition appears to be the main reason for the US must-carry/retransmission consent regulation, as it will be explained.

Must-carry rules by themselves could have followed the reasoning of multiple sources of information and viewers' rights, but when retransmission consent rules are added to must-carry rules, a major question arises. Are viewers' rights and the possibility of their having access to multiple sources of information really the basis for these regulations? No, because if there had been a major public policy concern that without free-to-air TV channels viewers would be deprived of multiple sources of information, then retransmission consent would not have been allowed. In other words, by including

\footnotetext{
${ }^{7}$ US Census Bureau reports that in 1997 only $18 \%$ of households had internet subscriptions, and in 2000 such percentage increased to 41.5\%. U.S. Census Bureau, Appendix Table A. Households with a Computer and Internet Use: 1984 to 2009, Computer and Internet Use in the United States: 1984 to 2009, 2010), available at https://www.census.gov/data/tables/time-series/demo/computer-internet/computer-use1984-2009.html.
} 
retransmission consent as an alternative to must-carry rules, US public policy signaled that multiple sources of information through free-to-air TV channels were subject to broadcasters' private interests and their negotiations with payTV companies, thus diluting the objective of having multiple sources of information.

The case of satellite pay-TV is different. First, satellite pay-TV may be provided on a nationwide basis. Second, the number of local TV stations in the US to the carried by DBS services would make retransmission through satellite services excessively costly and perhaps technically unfeasible.

Notwithstanding the above, internet access through multiple platforms challenges whether viewers' rights and multiple sources of information could be nowadays a reason to maintain must-carry rules provided that as of $2015,77.2 \%$ of households had internet subscriptions and $76.5 \%$ of them are of broadband (U.S. Census Bureau, S2801, 2015), and by 2018 households have internet access amount to $87 \%$ (ITU ICT-Eye), which enables people to access to text, images, audio and videos from local and worldwide sources. This will be further discussed in Part IV.

\section{The ivi Case}

The ivi case. ivi was a company that offered video streaming services for a monthly fee. The programming was copyrighted TV programming which was transmitted live, without the copyright holders' consent. Subscribers were able to access TV programming by downloading it onto their ivi TV player device; they could also record, pause it, and fast forward content. Consequently, the producers and owners of the copyrighted TV programming sued ivi for copyright infringement and sought an injunction to prevent ivi from continuing to stream their works. ivi argued that since it offered video services online, it should be considered a cable system and thus entitled to a compulsory license under the Copyright Act (WPIX, Inc. v. ivi, Inc., 2012).

In the appeal filed by ivi against the injunction granted by the District Court to prevent the retransmission of programming, besides reaffirming the decision, the United States Court of Appeals for the Second Circuit acknowledged that the intent of Congress was unclear in terms of whether internet video services constituted a cable system and would then benefit from compulsory licensing. The opinion evoked the congressional objectives of such compulsory licensing, namely, by addressing the issue of poor television reception and to "(...) support localized -rather than nationwide- systems that use cable or optical fibers to transmit signals through `a physical, point-to-point connection between a transmission facility and the television sets of individual subscribers.'" (WPIX, Inc. v. ivi, Inc., 2012, p. 283). 
In the case in question, the Court of Appeals found that the internet was nationwide rather than local and that videos made accessible via the internet - as in the case of ivi's services - were easing access rather than providing access. Moreover, it found that the Copyright Office had held that internet retransmissions were not cable system services, thus providing more grounds for its decision.

Both the ivi and French PlayTV cases, as well as the criteria adopted by the Mexican regulator evidence that there is tension between the reasons of must-carry rules when they were enacted and their applicability upon new platforms, as will be discussed in Part IV.

\section{MUST-OFFER THE IMPORTANT RULE IN MEXICO}

Mexico's free-to-air TV programming has long been dominated by two corporate groups in terms of both the number of commercial licenses and the audience share: Televisa and TV Azteca (Instituto Federal de Telecomunicaciones, Public Bid IFT-1, 2014). ${ }^{8}$ A new nationwide license was granted in 2015 for ImagenTV (Instituto Federal de Telecomunicaciones, License Agreement for Cadena Tres, 2015), which started operations in 2016 (SDPnoticias.com, 2016). Since then, its audience share has yet to grow. Public TV broadcasting amounts to a very low share of the audience standing at $2 \%$ (Instituto Federal de Telecomunicaciones, Resolución, Broadcasting Preponderant Agent Resolution, 2014).

From a pay-TV standpoint, Televisa is also a major player controlling a total of $60.9 \%$ of the entire market with its cable and satellite companies, ${ }^{9}$ whereas TV Azteca has $3.2 \%$ of the pay-TV market (Instituto Federal de Telecomunicaciones, Third Quarter Statistical Report 2018). ${ }^{10}$ América Móvil is by far the largest fixed and mobile telephony and broadband corporate group in Mexico (Instituto Federal de Telecomunicaciones, Third Quarter Statistical

\footnotetext{
${ }^{8}$ Televisa and TV Azteca jointly hold - either directly or through subsidiaries/affiliates95 percent of the commercial licenses, 90 percent of audience share, and 99 percent of the advertisement income.

${ }^{9}$ Televisa holds a market share of $46.4 \%$ in cable TV and $71.5 \%$ in satellite TV (Third quarter of 2018). Instituto Federal de Telecomunicaciones, Third Quarter Statistical Report 2018, p. 17.

${ }^{10}$ Only considering cable and satellite TV, TV Azteca holds a market share of $3.2 \%$, Instituto Federal de Telecomunicaciones, Third Quarter Statistical Report 2018, p. 17.
} 
Report 2018), ${ }^{11}$ but due to restrictions in one of its license, it may not provide pay-TV services. $^{12}$

A key factor in the market success of pay-TV in Mexico was whether programming packages offered Televisa's channels 2 and 5 because Mexican viewers were willing to subscribe to pay-TV only if those Televisa channels were included, as acknowledged by the former Mexican Federal Commission of Economic Competition (Cofeco) (Comisión Federal de Competencia, 2006). ${ }^{13}$ Consequently, pay-TV providers were willing to carry those channels and to pay to Televisa for such carriage. This allowed Televisa, as both a broadcaster and a pay-TV company, to leverage its market position vis-à-vis other pay-TV companies. Consequently, Cofeco imposed a must-offer obligation on Televisa in 2006 as a condition to allow Televisa to acquire other pay-TV companies (Comisión Federal de Competencia, 2012). Televisa began to offer its free-to-air channels as a bundle (Televisa, 2008). ${ }^{14}$ Televisa's dominance over the audience share of free-to-air programming means the must-carry rule has not been as important in Mexico as the must-offer rule has.

Years later, must-carry/must-offer rules were part of the measures proposed to foster competition in radio and television (Pacto por México, 2012, commitment 43) through the so-called Pact for Mexico. This pact stemmed from an ambitious policy agenda, including major reforms in both telecommunications and broadcasting.

A couple of months after the Pact for Mexico was signed, the Mexican Constitution was amended to include must-carry and must-offer rules. A different regime for must-carry/must-offer rules, or a Mexican version of them, is in force by constitutional order and includes mandatory retransmission without any payment whatsoever. Although must-carry/must-offer rules appear to have the underlying motive of protecting viewers' rights, preserving national

\footnotetext{
${ }^{11}$ América Móvil's market share is of $57.6 \%$ in fix telephony, $63.3 \%$ in mobile telephony, $51.9 \%$ in fix broadband and $71.6 \%$ in mobile broadband, as of the third quarter of 2018. Instituto Federal de Telecomunicaciones, Third Quarter Statistical Report 2018, pp. 15 $16,19-20$.

${ }^{12}$ The license is of America Movil's fix operator, Télefonos de México (Telmex). Secretaría de Comunicaciones y Transportes, Modificación al Título de Concesión de Teléfonos de México, S.A. de C.V. (Mexico), August 10, 1990, § 1.9.

${ }^{13}$ This was challenged by Dish when it entered into an alliance with Telmex by virtue of which Dish benefited from the Telmex installed customer base and despite not having Televisa's channels 2 and 5, Dish became a disruptive competitor.

${ }^{14}$ It is important to note that in its public offer Televisa expressly excluded pay-TV providers with more than 5 million users and US\$1.5 billion. This exclusion could only apply to: América Móvil. Televisa, Aviso para Concesionarios de Televisión y Audio Restringidos [Notice for Pay Television and Audio Operators], El Universal, Mex. Jan. 3, 2008, B5.
} 
ties and fostering diversity and plurality, the real reason was because of competition as explained below.

The only case resolved by the Mexican Supreme Court in connection with must-carry/must-offer rules is explained to highlight certain mustcarry/must-offer objectives identified in the decision. Lastly, this part presents Mexican telecommunications regulator (Instituto Federal de Telecomunicaciones or IFT) criteria on the rejection of must-carry obligations for online video distribution operators.

\section{Mexican Must-Offer and Must-Carry Rules}

In 2013, the Mexican Constitution was amended and must-carry/mustoffer obligations were included therein (Mexican Constitution's Amendment on Telecommunications, 2013). Although the reasons and objectives for mustcarry/must-offer rules were not explicitly laid out in the Constitution, the amendment discusses these rules more as a competition objective than as its main rationale.

The Mexican President's bill to amend the Constitution ${ }^{15}$ refers to payTV audience's right to receive free-to-air TV because it "aims at a social purpose" (Presidencia de la Republica, 2013). In its report on the mustcarry/must-offer rules, the Senate concluded that must-carry rules are the broadcasters' right for their channels to be included in pay-TV programming, and must-offer rules are presented as enabling the pay-TV audience to receive "contents with national ties and values."

It is important to note that Mexico does not have any regulation ordering broadcasters to include a minimum percentage of national production nor of investment on national production as other countries do (e.g. members of the European Union). Moreover, the IFT found that 9 out of 10 children's programs transmitted by commercial broadcasters, and 7 out of 10 children's programs transmitted by public broadcasters came from abroad (Instituto Federal de Telecomunicaciones, Studies of Children as Audience, 2015). Consequently, it is not clear whether free-to-air TV broadcasters do in fact convey national ties and values.

\footnotetext{
${ }^{15} \mathrm{~A}$ bill may be submitted by the Mexican president to either the Chamber of Deputies or to the Senate. Such Chamber will then be deemed the Chamber of origin. The bill is analyzed by one or more committees, and a report is prepared for deliberation before its being put up for vote. The report is then submitted to the Chamber of origin for further debate. If approved, it goes to the reviewing Chamber, which follows the same procedure. While ordinary legal amendments require a majority of votes to pass, constitutional amendments require 2/3 approval by both Chambers and a majority of the 32 State legislatures. Constitución Política de los Estados Unidos Mexicanos, arts. 71, 72 and 135.
} 
Mexican must-carry/must-offer obligations are sui generis, not only because they are incorporated into the Constitution, but because they also must be granted without any payment whatsoever. Must-offer rules order free-to-air TV broadcasters to allow pay-TV companies to retransmit their signals in the same coverage area without payment; whereas must-carry rules obligate pay-TV companies to provide audiences with these free-to-air TV channels without passing the transmission fees along to subscribers.

The must-carry/must-offer cost-free rules do not apply to companies that have been determined as having significant market power, or to those that have been declared preponderant carriers. ${ }^{16}$ This provision shows that mustcarry/must-offer rules seek to encourage smaller or newer pay-TV companies, hence, for purposes of competition.

Mexican Constitution states that "when competition exists in the telecommunications and broadcasting sectors" then free of charge retransmission will be over. This provision is relevant for two reasons: first, because must-carry/must-offer rules will continue whether or not there is competition in the telecommunications and broadcasting sector; and second, because, competition is one major public policy objective. If someday there is effective competition in those markets, then operators will have to agree on the conditions and tariffs for retransmission of free-to-air TV channels. In the event of any dispute around the tariffs, then the IFT will determine the tariff based on costs (Mexican Constitution Amendment on Telecommunications, 2013).

Federal public free-to-air TV channels must be included in all pay-TV packages, regardless of whether those channels can be viewed in the given geographical area. Although federal public free-to-air TV stations are controlled by the government and editorial independence is not guaranteed, they normally include more plural and diverse current affairs programs and content than commercial free-to-air TV stations. Consequently, this provision could be interpreted as advancing plurality and diversity. However, as long as public freeto-air TV stations are only accountable to the government and lack citizen participation and editorial independence, plurality and diversity cannot be assured.

\footnotetext{
${ }^{16}$ Preponderant carriers in telecom and broadcast are groups that hold more than $50 \%$ of national participation in such services based on the number of users, audience, network traffic or capacity. These companies must enter into agreements with free-to-air broadcasters to determine retransmission prices or risk license revocation. See Alvarez, C. L., 2015. The IFT also declared America Móvil (Telmex, Telcel, and other related companies) preponderant in the telecommunication sector and Televisa and its independent free-to-air TV affiliates (although not its pay-TV companies) as preponderant in the broadcasting sector. See Instituto Federal de Telecomunicaciones, Broadcasting Preponderant Agent Resolution, 2014.
} 
For satellite TV companies, the must-carry rule is ordered only in terms of free-to-air TV channels transmitted in at least 50 percent of the country (Mexican Constitution Amendment on Telecommunications, 2013). Televisa channels 2 (Las Estrellas) and 5, and TV Azteca channels 7 (Azteca 7), 7.2 (a+), 13 (now Channel 1), and $40(\operatorname{adn} 40)$ are the only ones to reach this percentage (Instituto Federal de Telecomunicaciones, Lineamientos, 2017). The reasoning behind this carriage was that satellite TV companies would have to incur disproportionate costs if they were obliged to carry all the free-to-air TV stations in the Mexican Republic. Moreover, there is limited satellite capacity to do that (Senado de la República, 2013).

Such a justification for must-carry rules for satellite TV services are evidently not for the purpose of ensuring the transmission of local news/programs; when a free-to-air TV channel has to cover $50 \%$ or more of the country, it necessarily excludes the possibility of addressing local interests in its programming. Plurality and diversity could not be the reason behind the mustcarry rule because Televisa and TV Azteca have not shown a commitment towards either plurality or diversity.

It is important to note that, when the Constitution refers to fee-free retransmission, it is connected to the relationship between free-to-air TV stations and pay-TV companies, ${ }^{17}$ as well as between pay-TV companies and their subscribers. Nothing was established regarding copyright royalties, nor was there any reference to this issue in the legislative process to amend the Mexican Constitution.

\section{Mexican Supreme Court's Ruling}

The Mexican Supreme Court decided one case regarding the mustcarry/must-offer rule. Although the issue at stake was whether copyright owners of any type of artistic work were entitled to additional payment for pay-TV company carriage of their broadcasted works under must-carry obligations (Suprema Corte de Justicia de la Nacion, Amparo en Revisión 1238/2015, 2016), ${ }^{18}$ it is important to identify the reasoning behind must-carry/must-offer rules in Mexico from the judiciary standpoint.

\footnotetext{
${ }^{17}$ In the EU, pay-TV companies may receive payment for carrying free-to-air channels; whereas in the USA, there could be either free carriage (must-carry) or an arrangement (retransmission consent) whereby broadcasters and pay-TV companies can agree to different terms (e.g. payment in kind with advertisement).

${ }^{18}$ The plaintiffs held copyrights on musical works that were transmitted on free-to-air TV channels and filed a judicial review (juicio de amparo) in order to assert their right to receive royalty payments for pay-TV company retransmission of their works under the must-carry obligation. Suprema Corte de Justicia de la Nacion (Mexico), Second Chamber, Amparo en Revisión 1238/2015, June 29, 2016.
} 
The Mexican Supreme Court acknowledged that must-carry/must-offer rules in the Constitution only regulate the relationship between TV broadcasters and pay-TV companies. Moreover, the principal objective of the mustcarry/must-offer rule is

\begin{abstract}
“(...) to have diversity, plurality and more access to content on pay-TV services in order to benefit all Mexicans, allowing them access to information and communication technologies; in addition to establishing conditions for free competition and free access so that more users can access such services under better terms of quality and price (...)." (Suprema Corte de Justicia de la Nacion, Amparo en Revisión 1238/2015, 2016) ${ }^{19}$
\end{abstract}

Regarding the denial of copyright holder's right to a royalty payment for the carriage of their broadcasted works, ${ }^{20}$ the Mexican Supreme Court deemed that it is not actually a case of retransmission of the signals, provided that these works are distributed through pay-TV companies at the same time and in the same area as the free-to-air TV channels. The Mexican Supreme Court concluded that the purpose of must-carry/must-offer rules is for free-to-air TV channels to be received by everyone -in the same area- free of charge (Suprema Corte de Justicia de la Nacion, Amparo en Revisión 1238/2015, 2016). This argument of the Mexican Supreme Court in a certain way evokes the initial cases of when the US Supreme Court denied a copyright infringement when cable TV operators retransmitted the free-to-air TV signals (Benjamin et al., 2012).

The Mexican Supreme Court did not elaborate on why it is important for everyone to receive free-to-air TV channels. Nevertheless, there are other

\footnotetext{
19“(...) el de que exista diversidad, pluralidad y mayor acceso de contenidos a los servicios de televisión restringida, para beneficiar a todos los mexicanos, permitiéndoles el acceso a las tecnologías de la información y la comunicación; además de establecer condiciones de competencia y libre concurrencia para que un mayor número de usuarios acceda a ellos en mejores términos de calidad y precio (...)".Suprema Corte de Justicia de la Nacion (Mexico), Second Chamber, Amparo en Revisión 1238/2015, June 29, 2016. ${ }^{20}$ It should be noted that the Court acknowledged copyright holders' right to royalty payment for the transmission of their works (the original distribution by free-to-air TV of the works), but denied additional compensation since by virtue of the must-carry rule these works would be also distributed by pay-TV companies. The Court also noted that if a pay-TV company does not distribute signals at the same time as the free-to-air broadcaster or if it distributes signals that are not available through free-to-air TV in the area, then the copyright holder is entitled to compensation because these cases fall outside the scope of the must-carry obligation.
} 
precedents stating that free-to-air TV and radio services have a social function linked to democracy (Suprema Corte de Justicia de la Nación, Tesis P./J. 69/2007, 2007). These precedents date from 2007 when internet access was available to only $22.2 \%$ of the population (Instituto Nacional de Estadística y Geografía, Estadísticas sobre Disponibilidad y Uso de Tecnología de Información y Comunicaciones en los Hogares 2007) (as of 2018, this percentage arised for $65.8 \%$ pursuant to Instituto Nacional de Estadística y Geografía, Encuesta Nacional Disponibilidad y Uso de Tecnologías de la Información en los Hogares (ENDUTIH) 2018). Therefore, it is debatable whether the Mexican Supreme Court would reach the same decision on the issue of democracy if most Mexicans had internet access in their day-to-day lives.

\section{Telecom Regulator Criteria}

The IFT ruled that must-carry obligations did not apply to entities that provide access to TV programming via the internet. The arguments for this interpretation were formalistic. pay-TV is defined by law as provided by a public telecom network with a command and transmission center, whereas TV via the internet is provided online, does not have a command and transmission center, and can be delivered regardless of location. Therefore, and despite the similarities in terms of the viewer, internet TV service is different from pay-TV service according to the IFT. Consequently, no must-carry obligation is imposed on internet TV providers. It is important to note that the regulator did not address any competition issues, plurality or audience rights in its rulings (Instituto Federal de Telecomunicaciones, Response to Maxcom, 2015, and Response to Alive Telecomunicaciones, 2015). ${ }^{21}$

\footnotetext{
${ }^{21}$ Instituto Federal de Telecomunicaciones, Acuerdo mediante el cual el Pleno del Instituto Federal de Telecomunicaciones emite respuesta a la solicitud de confirmación de criterio presentada por Maxcom Telecomunicaciones, S.A.B. de C.V., y Maxcom TV, S.A. de C.V., en el sentido de que el servicio a suscriptores y/o usuarios bajo contrato, consistente en el acceso codificado remoto a servicios de television, bajo la utilización de capacidades propias y adquiridas a otros concesionarios de redes públicas de telecomunicaciones con las que se tienen correlativos acuerdos, así como internet, se encuentra comprendido dentro de los servicios de interés público señalados en el Reglamento del Servicio de Televisión y Audio Restringidos [Response to the Maxcom Telecomunicaciones, S.A.B. de C.V. and Maxcom TV, S.A. de C.V. request for the confirmation of criteria], P/IFT/010715/165 (Mex. July 1, 2015); and Instituto Federal de Telecomunicaciones, Acuerdo mediante el cual el Pleno del Instituto Federal de Telecomunicaciones emite respuesta a la solicitud de confirmación de criterio presentada por Alive Telecomunicaciones, S.A. de C.V., en el sentido de que el "Servicio de Televisión Restringida por Internet, es un servicio público de telecomunicaciones, en términos del artículo 28 de la Constitución Política de los Estados Unidos Mexicanos y la Ley Federal de Telecomunicaciones y, en consecuencia estaría sujeto a las disposiciones aplicables en materia de retransmisión, obligaciones de información,
} 
In ivi case the Court of Appeals highlighted that the internet was not local, it was nationwide, and that the Copyright Office did not consider retransmission via the internet as a cable system. The IFT ruled also that internet TV service is not equivalent to public telecommunications networks (e.g., cable system), and that online TV could be accessed anywhere in the world which is also consistent with ivi case decision. However, both decisions are based on the technology/operator side, but not on the viewer's side. Technology neutrality would seek that regulation and judicial decisions be agnostic as to which device or network the viewer access to audiovisual content.

\section{MUST-CARRY AND MUST-OFFER RULES IN FRANCE}

France's must-carry/must-offer regulation has quite a different background from that of the USA and Mexico. In France, public broadcast TV channels were the only ones available until the 1980s (Group Le Figaro, 2018). The protection of pluralism, the representation of minority groups, and access to different opinions and ideologies were part of broadcasting objectives (Eijk and Sloot, 2012). Eijk and Sloot argue that must-carry rules were meant to retain some influence in the media landscape when private parties became broadcasters.

As a member of the EU, France must comply with the directives that govern electronic communications and audiovisual services. This section will first present the EU framework that forms the basis for must-carry/must-offer regulations in its Member States and the reasons behind it. EU grounds for the must-carry regime are to attain general interest objectives, which must be proportional, transparent and defined by each Member State. Moreover, each Member State may impose a must-carry regulation.

Very interesting peculiarities of possible must-carry regimes can be seen in each EU Member State. These specific traits will be compared to the mustcarry/must-offer regulations in the USA and in Mexico. This comparison shows that although the concepts of must-carry are used worldwide, each country has its own version of these rules.

To better understand the regime in France, must-carry/must-offer regulations are described. The must-carry regime is established in the law on freedom of communication, yet another piece of legislation (the Code Général

inscripción de contratos de adhesión y registro de tarifas al público, entre otras" [Response to the Alive Telecomunicaciones, S.A. de C.V. Request for confirmation of criteria], P/IFT/010715/164 (Mex. July 1, 2015). 
des Collectivités) on local public service also has a say in the carriage of local channels.

Finally, cases decided by the Paris Appellate Court and in the Conseil Constitutionnel are also presented to elaborate further. The first case, PlayTV, deals with an online video distribution service that started entering into agreements with private broadcasters but was unable to do so with public channels that belonged to France Télévision. Although PlayTV argued it had must-carry obligations, the Paris Appellate Court rejected the argument precisely because of the percentage of broadcast television viewers and the fact that PlayTV was a free service, unlike other electronic communications network operators that charged subscribers a fee. The case of the electronic network operators Iliad and Free is important because it addresses the importance of localism as a constitutionally valid objective for must-carry rules.

\section{The Must-Carry Framework in the European Union}

"Must-carry rules were originally developed to ensure the carriage of public channels (and other channels of special interest) over cable systems with the intention of securing the access for the public to these channels." (Kevin and Schneeberger, 2015, p. 14).

Eijk and Sloot affirm that the must-carry rules also addressed the concern that "private broadcasters and distributors would only focus on commercially attractive groups rather than on minorities." (Eijk and Sloot, 2015, p. 7).

Must-carry rules in the EU follow the rationale of competition since the economic viability of distribution networks deem that certain channels are essential for any programming package. Moreover, there is a cultural rationale that seeks certain public interest objectives, diversity, and the representation of minority groups (Kevin and Schneeberger, 2015, and Eijk and Sloot, 2015). Must-carry rules in the EU can also be considered viewers' or audience rights insofar as the ultimate goal is for people in the EU to have access to public interest broadcast channels.

At the EU level, Article 31 of the Universal Service Directive, which is part of the electronic communications directives, establishes:

\section{Article 31. "Must-carry" obligations}

1. Member States may impose reasonable 'must-carry' obligations, for the transmission of specified radio and television broadcast channels and complementary services, particularly accessibility services to enable appropriate access for disabled end-users, on undertakings under their jurisdiction providing electronic communications networks used for the distribution of radio or television broadcast channels to the public where a significant 
number of end-users of such networks use them as their principal means to receive radio and television broadcast channels. Such obligations shall only be imposed where they are necessary to meet general interest objectives as clearly defined by each Member State and shall be proportionate and transparent.

The obligations referred to in the first subparagraph shall be reviewed by the Member States at the latest within one year of 25 May 2011 except where Member States have carried out such a review within the previous two years.

Member States shall review "must-carry" obligations on a regular basis.

2. Neither paragraph 1 of this Article nor Article 3(2) of Directive 2002/19/EC (Access Directive) shall prejudice the ability of Member States to determine appropriate remuneration, if any, in respect of measures taken in accordance with this Article while ensuring that, in similar circumstances, there is no discrimination in the treatment of undertakings providing electronic communications networks. Where remuneration is provided for, Member States shall ensure that it is applied in a proportionate and transparent manner.

\section{Differences between EU, USA and the Mexican Must-Carry Regulations}

The Universal Service Directive sets the basis for any must-carry rules implemented by the EU Member States. These rules present several differences to those in the USA and Mexico.

(1) Must-carry rules may be established by the EU Member States. In the USA, must-carry regulations are established by law, yet broadcasters may choose between must-carry or retransmission consent. In Mexico, mustcarry rules are mandated by the Constitution and apply to all cable and satellite TV operators.

(2) Must-carry regulations are imposed on EU electronic communications networks. This means that not only cable TV and satellite TV are included, but also IPTV and any other network that distributes audio and video (e.g. mobile networks).

(3) EU electronic communications networks with must-carry obligations must have a significant number of end-users for whom the principal means of receiving free-to-air channels is said network. This requirement is nonexistent in must-carry rules in the USA and Mexico.

(4) Carriage in the EU may be mandatory for radio broadcast channels, TV broadcast channels, and complimentary services (e.g. accessibility services for users with disabilities). Moreover, these channels may originate from either public or commercial parties. In the USA and in Mexico, carriage 
obligations only apply to TV channels and may include both public and commercial channels.

(5) In the EU, must-carry rules must conform to the general interest objectives, which in turn must be proportional and transparent. There is no specific obligation in the USA or Mexico to further justify must-carry objectives.

(6) The EU Member States may determine proportional and transparent remuneration. In the USA, there may or may not be remuneration. This depends on the broadcaster to be carried because it may choose the mustcarry rule and waive any remuneration, or seek to negotiate via retransmission consent in which case it may receive remuneration. In the case of Mexico, there is no remuneration whatsoever, unless the pay-TV operator or broadcaster is a dominant or preponderant agent.

\section{France's Must-Carry and Must-Offer Rules}

In France, must-carry rules are established in the 1986 Law on Freedom of Communication (Loi No 86-1067 du 30 septembre 1986 relative à la liberté de communication), which governs electronic communication networks like cable, IPTV, satellite and mobile systems (Kevin and Schneeberger, 2015). The costs of carriage must be borne by network operators.

Public channels must be carried and are also subject to must-offer rules (Eijk and Sloot, 2015). The public channels include France Télévisions channels, ${ }^{22}$ TV5, the Parliamentary channel, Arte, ${ }^{23}$ and local channels. ${ }^{24}$

Local public channels must also be carried, while other local channels can be carried upon request (except for satellite TV services) (Kevin and Schneeberger, 2015). Analysys Mason identified local broadcasters' genuine interest in being distributed by ADSL. However, local channels faced challenges when negotiating their inclusion in pay-TV operators programming. Moreover, their inclusion represented the need for significant investment to be able to transmit their content in the required format. Finally, must-carry rules in France include services for people with hearing or visual disabilities (Loi $N^{\circ}$ 2011-901 du 28 juillet 2011 tendant à améliorer le fonctionnement des maisons

\footnotetext{
${ }^{22}$ France Télévisions covers channels France 2, France 3, France 4, France 5, and France Ô, www.france.tv.

${ }^{23}$ Arte (Association Relative à la Télévision Européenne) is a public European cultural channel. See www.arte.tv.

${ }^{24}$ There is no obligation for satellite TV to carry these channels.
} 
départementales des personnes handicapées et portant diverses dispositions relatives à la politique du handicap). ${ }^{25}$

\section{Important French Case Law on Must-Carry Issues}

The PlayTV case. PlayTV was a free online video distribution service. PlayTV displayed broadcast channels that were accessible online. PlayTV entered into agreements with private broadcasters and paid them an amount based on the number of broadcasters' programs being accessed by PlayTV users. Advertisements were displayed before the user could access the desired program.

This case arose because PlayTV initially tried to negotiate an agreement with France Télévisions to distribute its channels at the same time and without any changes. France Télévisions argued it could not enter into such an agreement because it did not have all the rights to transmit certain third-party programming via the internet. Although France Télévisions did have certain agreements with online video distributors, access was limited to their subscribers and the programming was not accessible on the open internet.

PlayTV then argued that because it was an electronic network distributor, it was entitled -and even legally obligated- to carry France Télévisions channels. PlayTV also modified the access to its services by including a webpage where users had to register and obtain a username and password to access French public channels.

The Paris Appellate Court noted that the law requires such companies to have subscribers and not mere users like PlayTV. Despite the fact that users had to $\log$ on with a username and password, it could not be considered a subscription service. Moreover, the decision pointed out that must-carry rules apply to electronic communications operators with a significant number of persons accessing television services through their network. In the case in question, the Paris Appellate Court found that only between 4-8\% of its viewers accessed broadcast television channels via the internet. Consequently, the court ruled that PlayTV was not entitled to benefit from must-carry rules (Cour d'Appel, 2016).

The Iliad and Free case. Local public channels must be carried and the costs of distribution and transportation must be borne by network operators. This obligation is only for channels that are within the geographic area of the network

\footnotetext{
${ }^{25}$ This law amended article 34 section III of the French Law No $86-1067$ of September 30, 1986 on freedom of communication, Loi $N^{\circ} 86-1067$ du 30 septembre 1986 relative à la liberté de communication.
} 
operators; in other words, subscribers are entitled to receive their community's or city's local public channels.

"[T] he municipality of Nice had entrusted the production, co-production, acquisition of rights and broadcasting of programs directed at local residents to the company Azur TV." (Blocman, 2017). Azur asked the Conseil Supérieur de l'Audiovisual to order the two companies -Iliad and Free- to distribute local programming to the subscribers of both companies.

Iliad and Free wanted to know whether the must-carry rule for local channels complied with the French Constitution. Their main arguments were that this must-carry obligation infringed their freedom to conduct business, their property rights and the equality principle in terms of public burdens.

The Conseil Constitutionnel ruled on the case, ${ }^{26}$ admitting that the mustcarry rule for local public channels did limit Iliad's and Free's constitutional rights. However, such restrictions were not inconsistent when taking into account the public interest objective of the carriage. The Conseil Constitutionnel asserted that according to the Code Général des Collectivités Territoriales, legislators had a public interest objective that consisted of maintaining and developing local public services through this must-carry rule. Moreover, the Conseil noted that the burden imposed on operators only comprised distribution and transportation, but not any other cost (e.g. civil engineering). Consequently, the Conseil Constitutionnel found the must-carry rule for local public channels in compliance with the French Constitution (Conseil Constitutionnel, March 23, 2016, Décision n ${ }^{\circ}$ 2015-529 QPC).

\section{RETHINKING MUST-CARRY RULES IN THE DIGITAL ERA}

Back in 1990, there was a limited number of ways to access audiovisual content via telecommunication platforms, namely, free-to-air TV and radio services, cable TV and satellite TV. The internet was not available except at the universities and institutions participating in the relevant projects ${ }^{27}$ in the USA and in France, whereas in Mexico, the first internet connections were established in 1994.

\footnotetext{
${ }^{26}$ The Conseil Constitutionnel has authority inter alia to decide on the constitutionality of laws and regulations, before and after their enactment. http://www.conseilconstitutionnel.fr/conseil-constitutionnel/francais/le-conseil-constitutionnel/presentationgenerale/presentation-generale.206.html (last visited on: May 13, 2019).

${ }^{27}$ Initially the project which gave origin to what today is the internet was known as ARPANET. Then there was the Computer Science Network (CSNET) and the NSFNET.
} 
Technological evolution has brought about a significant increase in access to content distribution platforms, especially in the $21^{\text {st }}$ century. Social networks as YouTube have contributed to changing the landscape also. "[B]y creating a platform for individual users to post videos, YouTube has helped to foster a whole new logic and political economy for content distribution" (Sylvain, 2017). The increased number of internet users, as well as that of fixed and mobile internet subscriptions, requires further analysis on whether current must-carry regulations still adhere to the reasons for which they were enacted in each country or if new mechanisms should be sought to reach the objectives of diversity, pluralism, localism, and so on.

This part presents data that indicates the penetration of television, telecommunications, and internet services over the last decades. A comparison of these data over the years enables better assessment of must-carry regulations. Otherwise, holding on to the praiseworthy objectives valid in the pre-digital era would only impose a burden on broadcasters and network operators without achieving anything.

Internet penetration, broadband width and an increased number of individuals using the internet are essential for such an assessment, but consideration must also be given to other issues, such as free-to-air radio and TV stations streaming their programming through their websites, cord-cutting and the availability of smart TVs.

An evaluation of must-carry regulations must take into account their rationale based on the different scenarios of a digital era. Therefore, Part IV presents an analysis of and reflections on competition, localism, multiple sources of information, diversity, and plurality. At the end of this part, discoverability is presented as one of the new alternatives to achieve must-carry objectives in the digital era.

\section{What Was and What is the Importance of Platforms for Society}

The availability of new electronic communication services and their increased penetration make it necessary to rethink the regulations imposed on providers. This section presents figures regarding household penetration of televisions and cable TV, the percentage of individuals using the internet, the percentage of fixed-broadband subscriptions, and the percentage of mobile internet subscriptions. This information is important to assess must-carry regulations and court decisions at the time such rules and decisions were enacted or pronounced, as well as the current situation of the telecommunication services in each country. 
United States of America. In the USA, the percentage of households with TV and of households with cable TV is important to understand policies and court decisions issued before the internet was widely available.

When the first cases of retransmission of free-to-air TV through cable systems were solved by the US Supreme Court (Fortnightly Corp in 1968 and Teleprompter in 1974), cable TV penetration in households was very low compared to the availability of TVs in households: $90 \%$ of US households had TV, but only $2.3 \%$ had cable TV in $1965 ; 97 \%$ of households had TV and $12.6 \%$ had cable TV in 1975 (U.S. Census Bureau, No. 1440). Since 1980, 98\% of households in the USA have TVs, nevertheless in 1980 only $19.9 \%$ had cable TV. By 1985, 42.8\% of US households had cable TV and, by 1992, up to $60.2 \%$ of households had cable TV (U.S. Census Bureau, No. 1440).

In this context, when the US Supreme Court decided that no copyright infringement was committed by cable TV operators that retransmitted free-to-air TV (1968 and 1974), cable TV was still the exception in US homes. Even when the compulsory license for retransmission was enacted in 1976 through the Copyright Act, cable TV was still a service used by few. However, the situation was very different when the Cable Act of 1992 established must-carry and retransmission consent rules because the percentage of households with cable TV was significant and there was no internet available for households yet. Moreover, when the US Supreme Court ruled on Turner II in 1997, the US Census Bureau carried out the first survey on households with internet subscriptions, finding that $18 \%$ of households had such subscriptions (U.S. Census Bureau, Appendix Table A, 2010), that is, having internet in homes was still an exception.

Regardless of the fact that internet subscriptions back in 1997 did not amount to what nowadays is considered broadband, $98 \%$ of the households had TVs and $66.5 \%$ had cable TV. In other words, few US households (18\%) had internet subscriptions and these were not broadband ones, so the internet could not have been deemed a substitute or an alternative for news and entertainment through free-to-air or pay-TV.

The percentage of US households with internet subscriptions has continuously grown from $41.5 \%$ in 2000 to $54.7 \%$ in 2003 and $68.7 \%$ in 2009 (U.S. Census Bureau, Appendix Table A, 2010). By 2015 in the USA, 77.2\% of the households had internet subscriptions, $76.7 \%$ of which were broadband (U.S. Census Bureau, S2801, 2015). For 2018 the households with internet access amounted for $87 \%$, having 31.5 of each 100 inhabitants as fixed broadband subscribers and 132.9 of each 100 inhabitants as mobile broadband subscribers (ITU ICT-Eye). 
Mexico. Mexico has a very different background from that of the USA and France. Mexico has very concentrated markets in terms of free-to-air TV stations, free-to-air viewers, pay-TV operators, and fixed and mobile broadband operators. Mexico has had a lower penetration of pay-TV services but is recently catching up on internet subscriptions.

In Mexico, by $1994,86.8 \%$ of households had TVs, but only $6.3 \%$ had cable TV (INEGI, Boletín de Política Informática No. 4, 2002). The following chart shows the evolution of the penetration of TV, cable TV and internet subscriptions.

\begin{tabular}{|c|c|c|c|c|}
\hline \multicolumn{5}{|c|}{ MEXICO } \\
\hline Year & $\begin{array}{c}\% \text { of } \\
\text { households } \\
\text { with TV }\end{array}$ & $\begin{array}{c}\% \text { of households } \\
\text { with pay-TV }\end{array}$ & $\begin{array}{c}\% \text { of individuals } \\
\text { using the } \\
\text { internet }\end{array}$ & $\begin{array}{l}\text { Fixed broadband } \\
\text { subscriptions per } \\
100 \text { inhabitants }\end{array}$ \\
\hline 2000 & $89.9 \%$ & $8.9 \%$ & $5.08 \%$ & 0.01 \\
\hline 2005 & $92.7 \%$ & $19.3 \%$ & $17.21 \%$ & 1.77 \\
\hline 2010 & $94.7 \%$ & $26.7 \%$ & $31.05 \%$ & 9.02 \\
\hline 2015 & $93.5 \%$ & $43.7 \%$ & $57.43 \%$ & 11.72 \\
\hline 2018 & $92.9 \%$ & $47.3 \%$ & $63.8 \%$ & 13.28 \\
\hline
\end{tabular}

Table 1 - Evolution of TV, cable TV and internet subscriptions penetration with information of International Telecommunications

Union (ICT Eye), and INEGI (Disponibilidad de tecnologías de

información y comunicaciones en los hogares, and ENDUTIH).

These data reflect that households with cable TV have increased significantly during the 20th Century, but the individuals using the internet have had bigger penetration comparing the same years. Moreover, in the third quarter of 2018, 66 of each 100 Mexican households had pay-TV, 53 of each 100 inhabitants had fixed access to the internet and 67 of each 100 inhabitants had mobile access to the internet (Instituto Federal de Telecomunicaciones, Third Quarter Statistical Report 2018).

Therefore, must-carry/must-offer rules in Mexico were initially imposed in 2006 but only upon the biggest broadcaster and pay-TV operator in Mexico: Televisa. Must carry/must offer rules can be deemed as two-sides of the same coin. If Televisa holds the largest market share of both free-to-air TV and of pay-TV subscribers, then such rules should be assessed with due regard to such fact.

Until 2013, when must-carry/must-offer were incorporated to the Mexican Constitution as a sui generis version of such type of regulation, as explained above in Part II.A, there had been no judicial review of such matter. The only must-carry/must-offer case decided by the Mexican Supreme Court in 
2016 did not elaborate on the penetration of free-to-air TV, pay-TV or internet subscriptions. Yet internet penetration and usage by inhabitants of Mexico should be considered when assessing whether the objectives of must-carry/mustoffer rules are achieved with the current rules.

France. In France, the percentage of individuals with internet access has steadily grown: it stood at $14.31 \%$ in 2000 , at $42.87 \%$ in 2005 , at $77.28 \%$ in 2010, and at $84.69 \%$ in 2015 (International Telecommunications Union, ICT Eye). ${ }^{28}$ Fixed broadband subscriptions have also grown from less than $1 \%$ in 2000 to $41.34 \%$ in 2015 , and as of $2018,40.5$ out of 100 inhabitants have such type of broadband subscription (International Telecommunications Union, ICT Eye). ${ }^{29}$ The number of mobile internet subscribers came to $36.49 \%$ of France's population in $2010,75.55 \%$ by 2015 , and 91.3 of each 100 inhabitants with mobile broadband subscriptions (ITU ICT-Eye). Therefore, the increase in internet access, as well as in both fixed and mobile broadband subscriptions shows that internet availability is currently pretty widespread among France's inhabitants.

Internet penetration and multiplicity of platforms. When the internet penetration of a given geographic area is low, then traditional broadcasting is dominant (Organization for Economic Co-operation and Development, 2013). In Mexico, free-to-air TV is still dominant due to low internet penetration and limited broadband capacity. In France, for example, it is estimated that "(...) nearly a third of the population remains disconnected either voluntarily, or because of enduring access restrictions. Partly as a result of this, television remains the primary source of news and information (followed by radio)." (Open Society Foundations, 2013). But if the data presented in this section show a steady increase in the number of individuals using the internet and acquiring broadband subscriptions, then the free-to-air TV will leave its predominant role and become simply another distribution platform, but not necessarily a prominent one.

Increased broadband penetration and computer power, as well as the availability of devices and applications, have changed the digital landscape in that users can receive content through different technological platforms and devices (Organization for Economic Co-operation and Development, 2013).

(...) the market of audiovisual media services has evolved significantly and rapidly. Technical developments allow for new types of services and user

\footnotetext{
${ }^{28}$ (International Telecommunications Union, ICT Eye)

${ }^{29}$ (International Telecommunications Union, ICT Eye)
} 
experiences. The viewing habits, particularly of younger generations, have changed significantly. While the main TV screen remains an important device to share audiovisual experiences, many viewers have moved to other, portable devices to watch audiovisual content. Traditional TV content accounts still for a major share of the average daily viewing time. However, new types of content, such as short videos or user-generated content, gain increasing importance and new players, including providers of video-on-demand services and video-sharing platforms, are now well-established. (Proposal for a Directive of the European Parliament and of the Council amending Directive 2010/13/EU).

Provided there is internet and broadband access, an individual may now access audiovisual content on a tablet, computer, mobile phone, television, and even on a digital watch. Content may be available on a website, a social network or a TV channel and may be accessible through free-to-air TV, a cable or satellite TV provider, or an over-the-top service (OTT) like Netflix, Hulu, Claro Video, etc. The foregoing was not possible when the Cable Act was enacted nor when Turner II was decided. Had it been possible perhaps must-carry rules in the Cable Act would not exist or they would be different, and Turner II opinion would have been argued and decided differently.

Broadcasters are now streaming their programming through their websites $^{30}$ or mobile apps. Sylvain states that "[o]nline streaming of broadcast programming poses one of the biggest threats to the traditional political economy of video production and distribution" (Sylvain, 2015, p. 740). Consequently, the question for policymakers is whether must-carry rules are still necessary today, considering the profound changes in both the multiplicity of platforms for accessing content and users' content consumption habits.

Cord-cutting. In the case of the USA, the cable TV industry is currently concerned about cord-cutting. This refers to cable TV subscribers who are canceling pay-TV services and only keeping internet access services (data services) that enable them to access audiovisual content through OTTs. If mustcarry obligations are imposed on cable TV providers and carry one, carry all upon satellite TV providers, but more and more people are choosing to end their pay-TV subscriptions (cord-cutting) and instead of using OTTs, the question

\footnotetext{
${ }^{30}$ In Mexico, the main free-to-air public and commercial TV channels may also been seen live online on the broadcasters' websites. E.g. Canal del Congreso at http://www.canaldelcongreso.gob.mx, Canal Once at http://oncetv-ipn.net/senal-internet/, Canal 22 at http://www.canal22.org.mx/p/internet/, Imagen Television at http://www.imagentv.com/en-vivo, Televisa at http://www.lasestrellas.tv/en-vivo/.
} 
should be whether the requirement of pay-TV operators having to carry free-toair TV signals is still justified.

Also, when the internet is widely available in households and through mobile devices in Mexico and France, users will also be able to do cord-cutting and to access online video services through diverse platforms. In other words, as more technological platforms are available for accessing content, competition is enhanced and users will have the final decision whether in the USA, Mexico, France or elsewhere to access through the platform of their choice.

Smart TVs. Smart TVs have emerged not only as new platforms but also as devices that enable users to access multiple platforms. These devices can provide access to free-to-air TV, pay-TV, internet, and OTTs. Consequently, as more people and households acquire smart TVs, can must-carry rules still be upheld when an individual can easily access any of those platforms on a smart TV? Access through smart TVs to any platform (free-to-air TV, pay-TV, internet, OTT) confer the choice of it to users.

Had smart TVs and internet access been available in 1992, the Cable Act would have had different or no must-carry rules at all since there would be no justification whatsoever for free-to-air TV carriage when a user from his household could access either free-to-air TV channels or pay-TV programming.

Had smart TVs been available in 1997 and internet access generally available in households, the Turner II case could have been decided differently, because through smart TV people could have had multiple sources of information (including local content). Regarding competition issues, Turner II would have found that there was a competition and it was not only between the operators of each platform (e.g., broadcasters vs. broadcasters fighting to attract more viewers and advertisers) but between all operators of all platforms available in a geographic area.

\section{Assessing Must-Carry Rules in the Digital Era}

Whether a given country currently achieves the original objectives of must-carry regulations is debatable.

“(...) must-carry requirement rests on the popular faith (and, now, fiction) that 'television broadcasting plays a vital role in serving the public interest' $(. .$.$) in$ today's market, this account about free, over-the-air broadcasting is more romance than reality, as fewer people every year rely on television antennas to watch broadcast programs. Most viewers subscribe to cable or use their internet connection to watch programming at a time and place that is convenient" (Sylvain, 2015, pp. 754-755).

When the US Supreme Court ruled on the Turner II case in 1997, 40\% of American households relied on free-to-air TV. It was recognized that 
"“broadcasting is demonstrably a principal source of information and entertainment for a great part of the Nation's population."' (Turner Broad. Sys. Inc. v. FCC, 1997, p. 190). Nowadays, with $88.8 \%$ of households with internet subscriptions (ITU ICT-Eye) plus the possibility of accessing the internet through mobile devices, does broadcast television hold the same status for accessing information and entertainment in the USA? Would the US Supreme Court now rule on upholding must-carry rules in the same way it did in 1997 ?

\section{Competition?}

Competition has been the main reason for must-carry rules in the USA and Mexico, and a significant one for France. Competition as a means to level the playing field has assumed that free-to-air TV on one side and cable and satellite $\mathrm{TV}^{31}$ on the other were the only existing platforms to distribute content. Although that was still true some years ago, it is no longer the case. As long as there is network availability, ${ }^{32}$ users can choose which device to use, as well as which platform and which content to access.

In the USA, both for the must-carry rules and the carry one, carry all rule, one of the underlying competition reasons to enact them was to preserve local free-to-air TV stations assuming that the existence of them was necessary for non- pay-TV viewers. However, when a person can access through multiple devices multiple news and entertainment services, is there a strong public policy objective in protecting local free-to-air TV stations but not other platforms? I do not think so, because then the government will be acting against the principle of technology neutrality and would be conferring privileges just to one technological platform.

Promoting fair competition was also expressed in must-carry rules in the USA and Mexico. Fair competition in video services should acknowledge the current technical availability of platforms to access videos and the degree of internet and broadband penetration. If there are several technological platforms (e.g., free-to-air TV, cable TV, OTT) to access audiovisual content, and the people have access to broadband, then fostering competition must also be technology-neutral, that is, without favoring or affecting any particular platform.

In this regard, the Dutch case that exempted a television app called Play from the must-carry regulation is important because the regulator made a distinction between an app and a cable network. The underlying reason was that

\footnotetext{
${ }^{31}$ In the case of France and members of the European Union, there is possibility of considering other electronic communication networks. However, OTTs are not included.

${ }^{32}$ Network availability is understood as having a network deployed, but it is also important for access to such a network to be affordable. Otherwise, no matter how many networks are available, users might face economic constraints.
} 
in the app world, there is no lack of competition or scarcity. Consequently, since end users have a sufficient range of channels to choose from, the must-carry objective for diversity and plurality would not apply to the app world (Kevin and Schneeberger, 2015, and Eskens, 2016). In other words, if there is competition in the app world and if viewers have options to choose from, why should must-carry rules be required the way they are today?

\section{Localism?}

Television in the USA is still deemed as a predominant pastime that carries great influence and the primary source of local news and information (Harvard Law Review, 2013). When the must-carry regulation was enacted, one of its objectives was to preserve localism in US cities and communities.

Pursuing localism assumes that (1) the content distributed by broadcasters is local or, at least, there is a local news and perhaps locally produced content (e.g. a documentary, a series); and (2) people value that local content. Are these assumptions true today? As seen in Section I.B above, there are mixed opinions. Therefore, an assessment must be performed to see whether local free-to-air TV stations are in fact distributing local news and content, whether people in the community do in fact view such programming, and whether people in the community can access to local news/entertainment through other platforms (e.g., websites).

Moreover, there must be an assessment of whether localism is achieved through must-carry rules, whether such rules should continue to exist in their present form or whether there could be alternative mechanisms to achieve localism. Perhaps on the internet, local news succumbs among so many national and worldwide news. Perhaps if there are no funds to produce local news and content, the cost of producing them and the likelihood of people reading/viewing them will be a disincentive to local content generation. This should be taken into account also when rethinking how to further reasons as localism in the digital era.

In France, the Conseil Constitutionnel held that the carriage of local public channels had a public interest in maintaining and developing local public services. If local services are to be met, perhaps the must-carry regulation must be amended to allow other platforms to provide access to local public services through websites, social networks, and so on. That is, to pretend that by imposing carriage obligations upon network operators (e.g., cable TV) regarding local programming or content, would be not only ignoring the principle of technology neutrality that should govern public policy but also -and more importantly-, it would be ignoring that people from the communities would be 
better served if such type of programming and content is distributed through websites, mobile apps, social networks, etc.

Now, if there is much more access to content, news, and information through multiple platforms like those enabled by the internet (websites, OTTs, and social networks) (Analysis Mason, 2010), ${ }^{33}$ then, must-carry regulation should be modified if localism and local public services are to be fostered. The functionality of search engines that provide information and links to websites based on the geographic location could also contribute.

So, more than modifying must-carry rules, it might make more sense to use alternative mechanisms as can be the establishment of funds to develop local content and distribute it through diverse platforms via the internet (Harvard Law Review, 2013). Otherwise, the aim of availability of and user exposure to local news, content, and services would be at best limited to its carriage on cable and satellite TV operators. Another option would be to use government advertising budgets to fund local news media (Harvard Law Review, 2013), following the Principles on the Regulation of Government Advertising in the Inter-American System for the Protection of Human Rights (Organization of American States, 2010).

\section{Multiple Sources of Information}

The availability of multiple sources of information has been another objective of must-carry regulations in the USA. Nonetheless, in view of the vast majority of individuals with access to the internet in the USA and the possibility for these individuals to access sources of information from all over the world, is this objective still valid for maintaining must-carry rules as they stand today? No, because with internet and broadband access, an individual can access an endless number of sources of information.

Data from the percentage of households with TV and cable TV vis-à-vis the percentage of households with internet subscriptions are also relevant. On the occasion of Turner II, such percentages were $98 \%, 66.5 \%$, and $18 \%$, thus the decision of the US Supreme Court could not have taken into account access through the internet to multiple sources of information as an alternative to TV. But today it is quite different. There is a myriad of news and entertainment

\footnotetext{
${ }^{33}$ Analysys Mason in France found that there were 45 local broadcasters in 2010, almost $50 \%$ of which was carried by cable or via ADSL, whereas very few were distributed by satellite operators. Interestingly, by 2009, 36 of these broadcasters were already transmitting via the internet. Analysis Mason, Etude portant sur les conditions de réussite de la télévision locale en France sur la base d'une comparaison internationale [Study on the conditions of the success of local television in France based on an international comparison], (October 2010), pp. 15 and 22.
} 
options through the internet, and people can access considering that just from a household perspective $87 \%$ have access to the internet without counting mobile internet access.

Moreover, in the USA, the must-carry regulation was also justified as a way to preserve options for non- pay-TV viewers, but if a high percentage of households now have access to online video services through fix and mobile broadband connections, then although they do not have pay-TV, they do have many options for news and entertainment through internet, hence must-carry regulations should be amended.

\section{Diversity and Plurality}

Diversity and plurality as a reason for must-carry rules assume that freeto-air TV is a platform that presents different points of view and ideologies, as well as open spaces for minority representation through audiovisual content, news, etc. Whether these assumptions are accurate or not depends on an assessment of each free-to-air TV channel.

In the Mexican case, it is clear that commercial free-to-air TV stations do not represent diversity or plurality, whereas public free-to-air TV stations lack editorial independence from the government. Thus, diversity and plurality in programming may be a desirable outcome, but not a mandatory one. Consequently, public free-to-air TV stations could be a forum for diversity and plurality, but that always depends on the political will of the Mexican government in office. So, for Mexico, must-carry regulation does not confer diversity or plurality. Therefore, other mechanisms should be pursued to achieve those objectives. One possibility could be including a percentage of programming from independent producers or journalists, and opening spaces for programming made by minorities.

In the EU, the European Audiovisual Observatory for the European Commission acknowledges that "(...) the abundance of information and reception possibilities in the digital age makes the need for such [must-carry] rules redundant" (Kevin and Schneeberger, 2015). However, it also points out that must-carry regulations may still be valid to ensure cultural and political objectives, and promote market diversity (Kevin and Schneeberger, 2015). So, consideration should be given to analyze how can cultural and political objectives and market diversity be achieved through other ways different from must-carry rules.

It must be noted that although in the EU must-carry rules may be imposed within the Member States when they are necessary to meet a general interest objective, a must-carry rule would only be imposed on an operator where a significant number of users use it to receive radio and free-to-air TV 
channels. Therefore, the basis for must-carry rules in connection with diversity and plurality somewhat fade, because then there would be an acknowledgment that holding an operator to must-carry rules depends on whether end-users are using it to access radio and free-to-air TV. If plurality and diversity were the most relevant reason under must-carry rules in the EU, then all electronic communications networks would be obliged to carry the free-to-air channels because persons living in the EU would be entitled to receiving those channels that are meant to provide plurality and diversity, regardless of whether there was or was not a significant number of users that access them.

Open Society research on the redefinition of media landscape along with the growth of new media platforms (Open Society Foundations, 2014) concluded that although using internet services as a medium for the freedom of expression is still limited to citizens who are already engaged; diversity is more readily found in internet services than in mainstream voices (Open Society Foundations, 2013). Hence, perhaps public policy for diversity and plurality should be more directed at internet penetration and usage rather than at preserving or amending must-carry regulations.

\section{Discoverability}

Diversity and plurality in the digital era must be attained in different ways. As they stand today, must-carry regulations will certainly do little to achieve diversity and plurality. These regulations must be transformed and adapted. Discoverability might be one of the paths to follow, as well as media literacy. In this regard, discoverability is

"(...) the intrinsic ability of a given content to "stand out of the lot", or to position itself so as to be easily found and discovered. (...) It involves more than a content's mere presence on a given platform; it can involve keywords (tags), search algorithms, positioning within different categories, metadata, etc. Thus, discoverability enables as much as it promotes." (Wikipedia, Discoverability, 2016).

Discoverability requires considering several perspectives, actors, access platforms and technology mechanisms.

"Discoverability weaves its way between audience and content in a set of complex interactions consisting of marketing initiatives and strategies, but also public policies, commercial dealings, rapidly evolving business models, 
innovative technologies, and changing consumer habits." (Desjardins, 2016, p. 10).

The key for the audience being able to discover relevant content from a cultural, public interest, local or national standpoint, requires to analyze the multiple platforms for access, their own scope, and limits, and to take advantage of technology mechanisms (e.g., search engines, algorithms, recommendation engines). A Canadian research demonstrated that despite the use of technology mechanisms, word-of-mouth recommendations by coworkers, friends and so on, was the main method of content discovery (Desjardins and Kornfeld, 2016). Discoverability should be part of further research to duly assess the need for promoting public policies on discoverability as a complement or in lieu of mustcarry regulation.

\section{CONCLUSION}

Free-to-air TV services have long enjoyed the nature of service with social value. In the digital era, free-to-air services are not meant to disappear, but rather shift from their predominant role to become just another platform to access audiovisual news and entertainment content.

Over time, must-carry regulations have been enacted in countries under different reasons and with diverse rules. The USA, Mexico, and France have all shared the competition rationale for must-carry rules. The USA and France have also argued that must-carry regulations contribute to localism. Mexico and France have must-carry regulations for diversity and plurality. Courts in the USA, Mexico, and France have decided on cases in which they reject the assumption that the must-carry regulation applies to online video distribution services.

It is time to ask whether in the digital era must-carry regulations should be preserved as they are now. In-depth analysis and amendments are now required to ensure that the original public policy objectives are met. Competition, localism, viewers' rights, access to multiple sources of information, diversity, and plurality must be analyzed from the point of view of the current availability of platforms to access the content.

New platforms to access content will most likely eliminate the justification for must-carry regulations as they stand today. If internet connections are available for individuals to access diverse platforms, then mustcarry regulations need to consider the possibility of having such users and their consumption habits. New technology should not be forgotten in public policy decisions but should form part of the assessment to confirm whether such 
regulation is needed. Otherwise, traditional platforms such as free-to-air TV or cable TV will needlessly support certain burdens without fulfilling any public policy objective. Internet and broadband penetration and availability require that an amendment is made to must-carry regulations and that other mechanisms are implemented in order to reach the objectives set forth in public policies for the digital era.

\section{REFERENCES}

ALI, C. Media Localism. Champaign: University of Illinois Press, 2017.

ALVAREZ, C. L. Preponderant Agent, what is that? The Law, State, and Telecommunications Review, Brasilia, v. 7, n. 1, p. 13-36, May 2015.

ALVAREZ, C. L. Telecomunicaciones y Radiodifusión en Mexico. Mexico: Posgrado en Derecho UNAM, 2018. Available at https://bit.ly/2KvYWEa.

ALVAREZ, C. L. Espectro, Derechos Humanos y Mercado. Revista del Centro de Estudios Constitucionales. Año II, n. 3, p. 101-135, Julio-Diciembre 2016.

ANALYSIS MASON. Etude portant sur les conditions de réussite de la télévision locale en France sur la base d'une comparaison internationale [Study on the conditions of the success of local television in France based on an international comparison], October 2010.

BEARD, T. R.; FORD, G. S.; SPIWAK, L. J., STERN, M. An Economic Framework for Retransmission Consent. Phoenix Center Policy Paper, No. 47, 2013.

BENJAMIN, S. M.; SHELANSKI, H. A.; SPETA, J. B.; WEISER, P. J. Telecommunications Law and Policy. $3^{\mathrm{a}} \mathrm{ed}$., Durham: Carolina Academic Press, 2012.

BLOCMAN, A. Obligation to carry local public television services judged compliant with Constitution. IRIS, 2016-5:1/11, 2017. Available at http://merlin.obs.coe.int/iris/2016/5/article11.en.html.

CABLE TELEVISION CONSUMER PROTECTION AND COMPETITION ACT OF 1992 (Cable Act).

CODE OF FEDERAL REGULATION (USA). 47 CFR 76.65. 
COMISIÓN FEDERAL DE COMPETENCIA (MEXICO). Informe de Rendición de Cuentas de la Administración Pública Federal 20062012, [Accountability Report of the Federal Public Administration 20062012], 2012.

COMISIÓN FEDERAL DE COMPETENCIA (MEXICO). Opinión sobre los efectos en el proceso de competencia y libre concurrencia de la convergencia de las redes para la provisión de servicios de voz, datos y vídeo, [Opinion regarding the effects in the competition and free access process derived from the network convergence for providing voice, data and video services] November 28, 2006.

CONSEIL CONSTITUTIONNEL (FRANCE). Décision no 2015-529 QPC, March 23, 2016.

CONSTITUCIÓN POLÍTICA DE LOS ESTADOS UNIDOS MEXICANOS (MEXICO).

COUR D’APPEL (FRANCE). Paris, Pole 5 - Ch.1, February. 2, 2016.

DECRETO POR EL QUE SE REFORMAN Y ADICIONAN DIVERSAS DISPOSICIONES DE LOS ARTÍCULOS 6º $7^{\circ}, 27,28,73,78,94$ Y 105 DE LA CONSTITUCIÓN POLÍTICA DE LOS ESTADOS UNIDOS MEXICANOS (MEXICO) (Mexican Constitution Amendment on Telecommunications), published in the Federal Official Daily on June 11, 2013.

DESJARDINS, D. Discoverability: Toward a Common Frame of Reference - Part 1. Canada Media Fund, 2016.

DESJARDINS, D. AND KORNFELD, L., Discoverability: Toward a Common Frame of Reference - Part 2: The Audience Journey. Canada Media Fund, 2016.

EIJK, N. V.; SLOOT, B. V. Must-carry Regulation: a Must or a Burden? Amsterdam Law School Research Paper, No. 2013-02, January 15, 2013.

ESKENS, S. J. Dutch Telecom Company Granted Exemption from Must-Carry Rules for New App. IRIS Legal Observations of the European Audiovisual Observatory, 2016. Available at http://merlin.obs.coe.int/iris/2016/1/article26.en.html.

ESKENS, S. J. Dutch Telecom Company Granted Exemption from Must-Carry Rules for New App. IRIS Legal Observations of the European 
Audiovisual Observatory, 2016. Available at http://merlin.obs.coe.int/iris/2016/1/article26.en.html.

EUROPPEAN UNION. Directive 2002/22/EC of the European Parliament and of the Council of 7 March 2002 on universal service and users' rights relating to electronic communications networks and services (Universal Service Directive), 2002 O.J. (L108) 51, as amended by Directive 2009/136/EC of the European Parliament and of the Council of 25 November 2009, O.J. (L337) 11 (Universal Service Directive).

EUROPPEAN UNION. Proposal for a Directive of the European Parliament and of the Council amending Directive 2010/13/EU on the coordination of certain provisions laid down by law, regulation or administrative action in Member States concerning the provision of audiovisual media services in view of changing market realities, COM(2016) 287 final, May 5, 2016.

FEDERAL COMMUNICATIONS COMMISSION (USA). 26 FCC Red. 2718 (2011).

FOURTH FEDERAL CIRCUIT (USA). Satellite Broadcasting and Communications Association v. FCC, 275 F.3d 337 (4th Cir. 2001).

GRUPO LE FIGARO. Linternaute, Histoire de la Télévision. Linternaute. Available at http://www.linternaute.com/histoire/categorie/61/a/1/2/histoire_de_la_tel evision.shtml.

HARVAD LAW REVIEW. Tilling the Vast Wasteland: the Case for Reviving Localism in Public Interest Obligations for Cable Television, v. 126, pp. 1034-1055, 2013. Available at https://harvardlawreview.org/wp-

content/uploads/pdfs/vol126_public_interest_obligations.pdf.

HAZLETT, T. W. Digitizing "Must-Carry" under Turner Broadcasting v. FCC (1997), The University of Chicago Press Journals, v. 8, pp. 141-207, 2000.

Available at https://www.journals.uchicago.edu/doi/pdfplus/10.1086/scer.8.1147074.

INSTITUTO FEDERAL DE TELECOMUNICACIONES (MEXICO). Acuerdo mediante el cual el Pleno del Instituto Federal de Telecomunicaciones actualiza las señales radiodifundidas com cobertura de $50 \%$ o más del territorio nacional em términos de los Lineamientos Generales en relación con lo dispuesto por la fracción I 
del artículo Octavo Transitorio del Decreto por el que se reforman y adicionan diversas disposiciones de $\operatorname{los}$ artículos $6^{\circ}, 7^{\circ}, 27,28,73,78$, 94 y 105 de la Constitución Política de los Estados Unidos Mexicanos, en materia de telecomunicaciones [Decree with the updated channels with more than 50\% coverage in the Mexican Republic], published in the Federal Official Daily on December 20, 2017.

INSTITUTO FEDERAL DE TELECOMUNICACIONES (MEXICO). Acuerdo mediante el cual el Pleno del Instituto Federal de Telecomunicaciones determina el valor mínimo de referencia, a que se refiere el numeral 4.1.3.5 de las Bases de Licitación Pública para concesionar el uso, aprovechamiento y explotación comercial de canales de transmisión para la prestación del servicio público de televisión radiodifundida digital, a efecto de formar dos cadenas nacionales en los Estados Unidos Mexicanos (Licitación No. IFT-1). [Agreement whereby the Board of the Federal Telecommunications Institute determines the minimum benchmark, in reference to paragraph 4.1.3.5 of the Rules for Public Bid to concession the use, development, and commercial exploitation of transmission channels for the public provision of digital television broadcasting, in order to form two national networks in the United Mexican States (Bid No. IFT-1)], (Public Bid IFT-1), April 15, 2014.

INSTITUTO FEDERAL DE TELECOMUNICACIONES (MEXICO). Acuerdo mediante el cual el Pleno del Instituto Federal de Telecomunicaciones emite respuesta a la solicitud de confirmación de criterio presentada por Maxcom Telecomunicaciones, S.A.B. de C.V., y Maxcom TV, S.A. de C.V., en el sentido de que el servicio a suscriptores y/o usuarios bajo contrato, consistente en el acceso codificado remoto a servicios de television, bajo la utilización de capacidades propias y adquiridas a otros concesionarios de redes públicas de telecomunicaciones con las que se tienen correlativos acuerdos, así como internet, se encuentra comprendido dentro de los servicios de interés público señalados en el Reglamento del Servicio de Televisión $\mathbf{y}$ Audio Restringidos [Response to the Maxcom Telecomunicaciones, S.A.B. de C.V. and Maxcom TV, S.A. de C.V. request for the confirmation of criteria], (Response to Maxcom), P/IFT/010715/165, July 1, 2015.

INSTITUTO FEDERAL DE TELECOMUNICACIONES (MEXICO). Acuerdo mediante el cual el Pleno del Instituto Federal de Telecomunicaciones emite respuesta a la solicitud de confirmación de 
criterio presentada por Alive Telecomunicaciones, S.A. de C.V., en el sentido de que el "Servicio de Televisión Restringida por Internet, es un servicio público de telecomunicaciones, en términos del artículo 28 de la Constitución Política de los Estados Unidos Mexicanos y la Ley Federal de Telecomunicaciones y, en consecuencia estaría sujeto a las disposiciones aplicables en materia de retransmisión, obligaciones de información, inscripción de contratos de adhesión y registro de tarifas al público, entre otras" [Response to the Alive Telecomunicaciones, S.A. de C.V. request for confirmation of criteria], (Response to Alive Telecomunicaciones), P/IFT/010715/164, July 1, 2015.

INSTITUTO FEDERAL DE TELECOMUNICACIONES (MEXICO). Estudios sobre Oferta y Consumo de Programación para Público Infantil en Radio, Televisión Radiodifundida y Restringida, 2015 [Studies regarding the Offer and Consumption of Programming for Children as Audience of Radio, Free-to-Air Television and Pay Television, 2015] (Studies of Children as Audience). Available at http://www.ift.org.mx/sites/default/files/contenidogeneral/industria/estudi osninosfinalacc.pdf.

INSTITUTO FEDERAL DE TELECOMUNICACIONES (MEXICO). Lineamientos Generales en relación con lo dispuesto por la fracción I del artículo Octavo Transitorio del Decreto por el que se reforman y adicionan diversas disposiciones de $\operatorname{los}$ artículos $6^{\circ}, 7^{\circ}, 27,28,73,78$, 94 y 105 de la Constitución Política de los Estados Unidos Mexicanos, en materia de telecomunicaciones [Regulation regarding Must-Carry and Must-Offer provisions in the Mexican Constitution], (Must-Carry, Must-Offer Regulation), February 27, 2014.

INSTITUTO FEDERAL DE TELECOMUNICACIONES (MEXICO). Resolución mediante la cual el Pleno del Instituto Federal de Telecomunicaciones determina al grupo de interés económico del que forman parte Grupo Televisa S.A.B., Canales de Televisión Populares, S.A. de C.V., Radio Televisión, S.A. de C.V., Radiotelevisora de México Norte, S.A. de C.V., T.V. de los Mochis, S.A. de C.V., Teleimagen del Noroeste, S.A. de C.V., Televimex, S.A. de C.V., Televisión de Puebla, S.A. de C.V., Televisora de Mexicali, S.A. de C.V., Televisora de Navojoa, S.A., Televisora de Occidente, S.A. de C.V., Televisora Peninsular, S.A. de C.V., Mario Enríquez Mayans Concha, Televisión La Paz, S.A., Televisión de la Frontera, S.A., Pedro Luis Fitzmaurice Meneses, Telemisión, S.A. de C.V., 
Comunicación del Sureste, S.A. de C.V., José de Jesús Partida Villanueva, Hilda Graciela Rivera Flores, Roberto Casimiro González Treviño, TV Diez Durango, S.A. de C.V., Televisora de Durango, S.A. de C.V., Corporación Tapatía de Televisión, S.A. de C.V., Televisión de Michoacán, S.A. de C.V., José Humberto y Loucille, Martínez Morales, Canal 13 de Michoacán, S.A. de C.V., Televisora XHBO, S.A. de C.V., TV Ocho, S.A. de C.V., Televisora Potosina, S.A. de C.V., TV de Culiacán, S.A. de C.V., Televisión del Pacífico, S.A. de C.V., Tele-Emisoras del Sureste, S.Ade C.V., Televisión de Tabasco, S.A. y Ramona Esparza González, como agente económico preponderante en el sector radiodifusión y le impone las medidas necesarias para evitar que se afecte la competencia y la libre concurrencia, [Resolution by which the Board of the Federal Telecommunications Institute determines as the broadcasting sector preponderant agent the economic interest group formed by Grupo Televisa, as well as imposes the necessary measures to prevent adverse effects for competition and freedom to access], (Broadcasting Preponderant Agent Resolution) P/IFT/EXT/060314/77, March 6, 2014.

INSTITUTO FEDERAL DE TELECOMUNICACIONES (MEXICO). Título de Concesión para usar, aprovechar y explotar bandas de frecuencias del espectro radioeléctrico para uso comercial que otorga el Instituto Federal de Telecomunicaciones a favor de Cadena Tres I, S.A. de C.V. [License Agreement for using frequency bands for commercial use granted by the Federal Telecommunications Institute in favor of Cadena Tres I, S.A. de C.V.] (License Agreement for Cadena Tres) March 27, 2015.

INSTITUTO NACIONAL DE ESTADÍSTICA Y GEOGRAFÍA (INEGI) (MEXICO). Disponibilidad y Uso de Telecomunicaciones 2013, 2014, 2015 y 2016 [Availability and Use of Telecommunications 2013, 2014, 2015 and 2016]. Available at http://www.beta.inegi.org.mx/temas/ticshogares/.

INSTITUTO NACIONAL DE ESTADÍSTICA Y GEOGRAFÍA (INEGI) (MEXICO). Disponibilidad de tecnologías de información y comunicaciones en los hogares [The availability of information and communication technologies in households], Boletín de Política Informática No. 4, 2002.

INSTITUTO NACIONAL DE ESTADÍSTICA Y GEOGRAFÍA (INEGI) (MEXICO). Estadísticas sobre Disponibilidad y Uso de Tecnología de 
Información y Comunicaciones en los Hogares (ENDUTIH) [Statistics on the availability of information and communication technologies in households], 2007.

INSTITUTO NACIONAL DE ESTADÍSTICA Y GEOGRAFÍA (INEGI) (MEXICO). Estadísticas sobre disponibilidad y Uso de Tecnología de Información y Comunicaciones en los Hogares (ENDUTIH) [Statistics on the availability of information and communication technologies in households], 2005.

INSTITUTO NACIONAL DE ESTADÍSTICA Y GEOGRAFÍA (INEGI) (MEXICO). Estadísticas sobre disponibilidad y Uso de Tecnología de Información y Comunicaciones en los Hogares (ENDUTIH) [Statistics on the availability of information and communication technologies in households], 2010.

INSTITUTO NACIONAL DE ESTADÍSTICA Y GEOGRAFÍA (INEGI) (MEXICO). Estadísticas sobre Disponibilidad y Uso de Tecnología de Información y Comunicaciones en los Hogares y su Uso por los Individuos [Statistics on the availability of information and communication technologies in households and its use by individuals], 2015 .

INSTITUTO NACIONAL DE ESTADÍSTICA Y GEOGRAFÍA (INEGI) (MEXICO). Encuesta Nacional sobre Disponibilidad y Uso de Tecnologías de Información en los Hogares 2018 [National Survey on the availability and use of information technologies in households], 2019.

INTERNATIONAL TELECOMMUNICATIONS UNION, ICT-Eye. Available at https://www.itu.int/net4/itu-d/icteye/.

KEVIN, D.; SCHNEEBERGER, A. Access to TV platforms: must-carry rules, and access to free-DTT, European Audiovisual Observatory, 2015. Available at https://rm.coe.int/16807835e4.

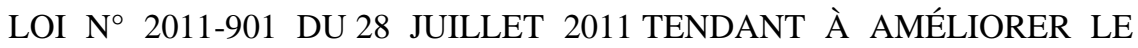
FONCTIONNEMENT DES MAISONS DÉPARTEMENTALES DES PERSONNES HANDICAPÉES ET PORTANT DIVERSES DISPOSITIONS RELATIVES À LA POLITIQUE DU HANDICAP (FRANCE). Journal Officiel de la République Française, July 30, 2011, p. 12996. This law amended article 34 section III of the French Law $N^{\circ}$ 86-1067 of September 30, 1986 on freedom of communication, Loi $N^{\circ}$ 86-1067 du 30 septembre 1986 relative à la liberté de communication. 
LOI N 86-1067 DU 30 SEPTEMBRE 1986 RELATIVE À LA LIBERTÉ DE COMMUNICATION (FRANCE). Journal Officiel de la République Française, October 1, 1986, 11755.

OPEN SOCIETY FOUNDATIONS. Digital Journalism: Making News, Breaking News, July 2014.

OPEN SOCIETY FOUNDATIONS. Mapping Digital Media: France, February 17, 2013.

ORGANIZATION FOR ECONOMIC CO-OPERATION AND DEVELOPMENT. Competition Issues in Television and Broadcasting, DAF/COMP/GF(2013)13, October 28, 2013.

ORGANIZATION OF AMERICAN STATES, Principles on the Regulation of Government Advertising in the Inter-American System for the Protection of Human Rights, 2010; Available at http://www.oas.org/en/iachr/expression/docs/reports/advertising/Govt\%2 0Advt\%20Principles\%202010.pdf.

PODER JUDICIAL FEDERAL (MEXICO). Radiodifusión. La sujeción de este servicio al marco constitucional y legal se da en el otorgamiento de concesiones $y$ permisos de manera transitoria y plural y con el cumplimiento de la función social que el ejercicio de la actividad exige por parte de los concesionarios y permisionarios. Pleno de la Suprema Corte de Justicia de la Nación, Semanario Judicial de la Federación y su Gaceta, Novena Época, tomo XXVI, Diciembre de 2007, Tesis P./J. 69/2007, Página 1092.

PRESIDENCIA DE LA REPÚBLICA (MEXICO). Iniciativa de Decreto por el que se reforman y adicionan diversas disposiciones de los artículos $6^{\circ}, 7^{\circ}, 27,28,73,78,94$ y 105 de la Constitución Política de los Estados Unidos Mexicanos, en materia de telecomunicaciones, [Bill of the Decree by which several provisions of articles $6^{\circ}, 7^{\circ}, 27,28,73$, 78, 94 and 105 of the Political Constitution of the United Mexican States are amended and added, in connection with telecommunications], March $11,2014$.

PRESIDENCIA DE LA REPÚBLICA, Pacto por México [Pact for Mexico], 2012. Available at http://www.presidencia.gob.mx/wpcontent/uploads/2012/12/Pacto-Por-México-TODOS-los-acuerdos.pdf.

SDPNoticias.com. Inicia Imagen TV Transmisiones. October 17, 2016 20:19. Available at https://www.sdpnoticias.com/nacional/2016/10/17/iniciaimagen-tv-transmisiones. 
SECOND FEDERAL CIRCUIT (USA). WPIX, Inc. v. ivi, Inc., 691 F.3d 275, 282-283 (2d Cir. 2012).

SECRETARÍA DE COMUNICACIONES Y TRANSPORTES (MEXICO). Modificación al Título de Concesión de Teléfonos de México, S.A. de C.V. [Amendment to the License Title in favor of Telefonos de México], August 10, 1990.

SENADO DE LA REPÚBLICA (MEXICO). Dictamen de las comisiones unidas de Puntos Constitucionales; de Comunicaciones y Transportes; de Radio, Televisión y Cinematografía; y de Estudios Legislativos, con la opinión de las comisiones de Gobernació y de Justicia, respecto de la minuta con proyecto de Decreto por el que se reforman y adicionan diversas disposiciones de los artículos $6^{\circ}, 7^{\circ}$, 27, 28, 73, 78, 94 y 105 de la Constitución Política de los Estados Unidos Mexicanos, en materia de telecomunicaciones, [Report of the united commissions of Constitutional Issues; Communications and Transportation; Radio, Television and Cinema; and of Legislative Studies, with the opinion of the Internal Affairs and of Justice commissions, in connection with the bill of the Decree by which several provisions of articles $6^{\circ}, 7^{\circ}, 27,28,73,78,94$ and 105 of the Political Constitution of the United Mexican States are amended and added, in connection with telecommunications], April 18, 2013.

SUPREMA CORTE DE JUSTICIA DE LA NACION (MEXICO), SECOND CHAMBER. Sentencia del Amparo en Revisión 1238/2015, June 29, 2016.

SUPREME COURT (USA). Turner Broad. Sys., Inc. v. FCC, 520 U.S. 180 (1997).

SYLVAIN, O. Disruption and Deference. Maryland Law Review, v. 74, p. 715-775, 2015.

SYLVAIN, O. Intermediary Design Duties. 50 Connecticut Law Review, v. 50, p. 203-274, 2018.

TELEVISA. Aviso para Concesionarios de Televisión y Audio Restringidos. El Universal, January 3, 2008, B5.

U.S. CENSUS BUREAU, No. 1440. Selected Communications Media: 1920 to 1998.

https://www.census.gov/history/pdf/radioownership1920-1998.pdf. 
U.S. CENSUS BUREAU. Appendix Table A. Households with a Computer and Internet Use: 1984 to 2009, Computer and Internet Use in the United States: 1984 to 2009 (2010), available at https://www.census.gov/data/tables/time-series/demo/computerinternet/computer-use-1984-2009.html.

U.S. CENSUS BUREAU. S2801, Types of Computers and Internet Subscriptions (2015).

WIKIPEDIA. Discoverability. Wikipedia, referring to Discoverability Summit (2016) of the Canadian Radio-television and Telecommunications Commission. Available at https://en.wikipedia.org/wiki/Discoverability\#cite_note-. 